\title{
The Role of Cathelicidins in the Innate Host Defenses of Mammals
}

\section{Margherita Zanetti}

Department of Biomedical Sciences and Technology, University of Udine, I-33100 Udine, and National Laboratory CIB, AREA Science Park, Padriciano 99, I34012 Trieste, Italy

\begin{abstract}
The cathelicidin peptides comprise one of several families of antimicrobial peptides that are found in neutrophils and epithelia as components of the early host defenses of mammals against infection. All cathelicidin family members are synthesized and stored in cells as twodomain proteins. These are split on demand to produce a cathelin protein and an antimicrobial peptide. Accumulating evidence indicates that both the cathelin portion and the C-terminal peptide exert biological activities connected with host protection. This review presents an overview of the structure and biology of cathelicidins and discusses recent progress in cathelicidin research with emphasis on the functional properties and role in host defense of the human cathelicidin hCAP18/LL-37. Although investigators initially concentrated their attention on antibiotic activity, it is becoming clear now that LL-37 is a multifunctional molecule that may mediate various host responses, and thus represents an essential component of the innate immune system in humans.
\end{abstract}

\section{Introduction and historical background}

The cathelicidins comprise a large number of precursors of antimicrobial peptides that typically contain a conserved $\mathrm{N}$-terminal sequence ('cathelin' domain) and a C-terminal antimicrobial domain of varied sequence and length (Fig. 1). The C-terminal peptides express antibiotic activity after they have been cleaved from the holoprotein, and current evidence indicates they may contribute to host defense by both direct pathogen inactivation and by other biological activities.

The discovery of cathelicidins can be traced back to the isolation of a disulfide-containing cyclic dodecapeptide during studies of the antimicrobial activity of bovine neutrophil lysates (Romeo et al., 1988). The identification of the dodecapeptide was soon followed by the purification of two additional neutrophil antimicrobial peptides that were designated bactenecins (after the latin words 'bacterium necare'). Bac5 is a C-terminally amidated peptide of 43 amino acid residues with a polycationic sequence characterized by a repeated proline motif; Bac7 is a 60-residue proline-rich peptide with distinct amino

For correspondence: Dept. Biomedical Sciences and Technology, University of Udine, P.le Kolbe 4, I-33100 Udine, Italy

Tel: +39-0432-494390; Fax: +39-0432-494301; E-mail: zanett@@icgeb.trieste.it acid sequence and proline motif (Gennaro et al., 1989). Cloning of the cDNA of Bac5 from a bovine myeloid cDNA library (Zanetti et al., 1993) was instrumental in showing that despite their diversity, dodecapeptide, bactenecins and yet other structurally unrelated antimicrobial peptides (Agerberth et al, 1991; Selsted et al., 1992; Kokryakov et al., 1993) were in fact closely related members of a single protein family. This became apparent during a molecular cloning step that was intended to amplify a Bac5 cDNA fragment from bovine bone marrow mRNA by pairing an oligo-dT primer with a forward primer based on a cDNA sequence upstream from the peptide coding region (Zanetti et al., 1993). Although the template sequence was thought to be unique to Bac 5 mRNA, a variety of additional transcripts were co-amplified using these primers. Each CDNA predicted a distinct peptide sequence that was attached to a propiece showing $75-87 \%$ sequence identity to the corresponding Bac5 propiece (Zanetti et al., 1995). The diverse C-terminal peptides turned out to be either previously isolated or novel antimicrobial peptides. A molecular cloning strategy was then devised based on the highly conserved $\mathrm{N}$-terminal propiece, to enable the identification of further members of this novel protein family in other species as deduced from cDNA. Newly discovered cathelicidin family members were designated after the putative C-terminal antimicrobial domain, by using acronyms (e.g., CRAMP for 'cathelin-related antimicrobial peptide' or BMAPs for 'bovine myeloid antimicrobial peptides'), one-letter symbols of key amino acid residues followed by the number of residues of the antimicrobial domain (e.g., LL-37), or referring to other specific peptide features. Sequences corresponding to this domain served as templates for chemical synthesis of peptides that were then functionally characterized.

The N-terminal propiece of approximately $11 \mathrm{kDa}(99$ to 114 residues) is the hallmark of cathelicidins (Zanetti et al., 1995). It generally shares higher than $70 \%$ sequence identity to cathelin, a protein that was isolated from porcine neutrophils as an inhibitor of cathepsin L (cathe-l-in is an acronym for cathepsin $L$ inhibitor) (Kopitar et al., 1989) prior to the initial recognition of the cathelicidin family. As will be discussed later, the structural features of porcine cathelin suggested it was a member of the cystatin superfamily of cysteine proteinase inhibitors (Ritonja et al., 1989).

\section{Definition and structural diversity}

The term 'cathelicidins' was proposed in 1995 to acknowledge the evolutionary relationship of the novel protein family to cathelin (Zanetti et al., 1995) and it is used to denote holoproteins that contain a cathelin-like sequence and a cationic antimicrobial domain.

The mature antimicrobial peptides (Table 1) will be referred to here as cathelicidin peptides. The mammalian cathelicidin peptides display a wide repertoire of 


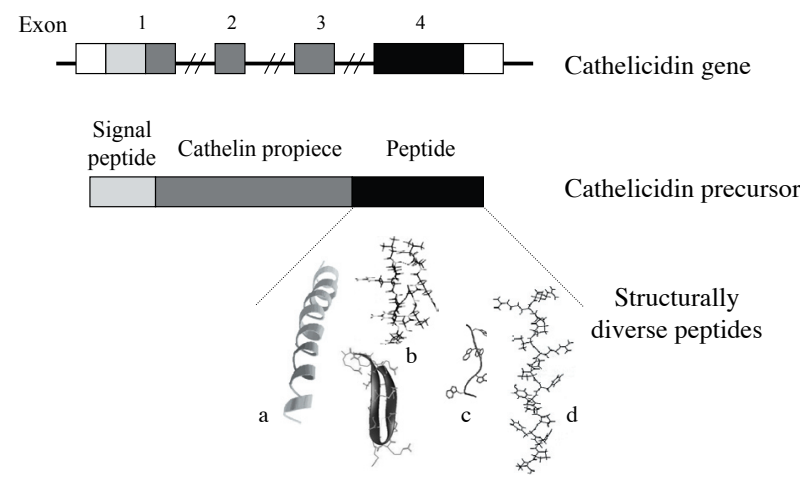

Fig. 1. Schematic representation of the gene and protein structure of cathelicidins. The mature cathelicidin peptides include $\alpha$-helical (a), cysteine-rich (b), tryptophan-rich (c) and proline-rich (d) peptides.

structures and include linear and cyclic molecules (reviewed in Gennaro and Zanetti, 2000). No obvious homology is generally shared with other antimicrobial peptide sequences and the diversity in size and sequence within this family appears to be remarkably higher than within any other antimicrobial peptide family. Peptides that assume $\alpha$-helical conformations in environments mimicking biological membranes are most common and either one or several peptides of 23 to 40 amino acid residues within this structural group have been found in every mammal examined. These peptides however are quite distinct from the $\alpha$-helical peptides described from insects, amphibians and fish (Tossi et al., 2000). Other linear cathelicidin peptides include an extended 13-mer named indolicidin, which contains 3 regularly spaced proline residues and an unusually high proportion of tryptophan (5 Trp) and a few proline-rich peptides ranging in size from 39 to 80 amino acid residues that show different types of proline repeat motifs in their sequences, namely, PR-39, Bac5, Bac7 and prophenins. Structural studies of PR-39 and Bac5 have indicated a polyproline II helix as the probable biologically active conformation of these peptides. Cyclic peptides include the protegrins and dodecapeptides. Protegrins (PG-1 through PG-5) are a 5-member group of 16-18 residue peptides characterized by two intrachain disulfide bonds and amidated C-termini. NMR spectroscopy of PG-1 indicates a two-stranded antiparallel $\beta$-sheet structure, with strands connected by a $\beta$-turn that results in an amphipathic conformation with a central hydrophobic region and two hydrophilic ends. The two-cysteine- containing dodecapeptide was suggested to be a 12 residue loop stabilized by a disulfide bond although mass spectrometric and SDS-PAGE analyses of the native molecule are rather consistent with a dimeric peptide stabilized by intermolecular disulfides. Further functional and structural information on cathelicidin peptides can be obtained from Gennaro and Zanetti, 2000 and from the AMSDb database at <www.bbcm. units.it/ tossi/antimic.html>.

\section{Antimicrobial activity}

Cathelicidin peptides display typical features of antimicrobial peptides, including a net positive charge at neutral $\mathrm{pH}$, due to a predominance of basic residues in their sequences, and an overall amphipathic topology.
When tested for in vitro antimicrobial activity, most peptides rapidly kill a wide range of microorganisms at micromolar and sub-micromolar concentrations, with a generally broad spectrum but significant differences in specificity and potency (reviewed in Gennaro and Zanetti, 2000, Zanetti et al., 2002). In vitro assays have proven a valuable means to assess antimicrobial features, albeit with an inevitable degree of variability in results generated by different laboratories, mainly due to the use of different methodologies (i.e., microbiological dilution assays, inhibition zone assays in solid media, fluorescence assays to monitor microbial death) and/or differences in the reagents (use of different microbial strains or different magnitudes of bacterial inocula, composition of incubation media). Furthermore, in vitro screening methods usually consider the activity of individual molecules, whereas several peptides and other biological substances that may cooperate to mutually increase the antimicrobial efficacy are present in vivo (Nagaoka et al., 2000; Yan and Hancock, 2001; Zarember et al., 2002; Dorschner et al., 2003; Midorikawa et al., 2003). For these reasons, the results obtained in vitro may not fully reflect the contribution of these molecules to microbial killing in vivo.

With few possible exceptions (proline-rich peptides and the loop form of dodecapeptide) the killing mechanism is mediated by disruption of the integrity of bacterial membranes (Gennaro and Zanetti, 2000). The $\alpha$-helical peptides SMAP-29 and BMAPs, from sheep and cows, respectively, and the two-disulfide bridged protegrins from pigs are amongst the most rapid and potent. Their spectra of activity encompass Gram-negative and Grampositive strains, including clinically relevant and multidrug resistant bacteria, fungal species, parasites and enveloped viruses (Saiman et al., 2001; Zanetti et al., 2002; McGwire et al., 2003; Giacometti et al., 2003a). Conversely, those showing proline-rich sequences are predominantly active against Gram-negative organisms in physiological salt concentrations (Gennaro et al., 2002). Another important feature of these peptides is their capacity to bind and neutralize bacterial endotoxin in vitro (Wiese et al., 2003), which may account for the ability of exogenously administered peptides to protect in vivo against sepsis (Giacometti et al., 2003b; Warren et al., 2003).

\section{Distribution}

\section{Species distribution}

Cathelicidins have been found in every mammal that has been examined, with substantial interspecies variation in the number of different family members. Only one has been described in humans (Agerberth et al., 1995; Cowland et al., 1995; Larrick et al., 1995), monkeys (Bals et al., 2001; Zhao et al., 2001), mice (Popsueva et al., 1996; Gallo et al., 1997), rats (Termen et al., 2003), rabbits (Larrick et al., 1991), guinea pigs (Nagaoka et al., 1997) and dogs (GenBank accession number NM_001003359). Three members have been identified in horses (Scocchi et al., 1999). The corresponding mature peptides in these species are invariably of the $\alpha$-helical type. Pigs (Storici and Zanetti, 1993a and 1993b; Storici et al., 1994; Zhao et al., 1994; Zanetti et al., 1994; Strukelj et al., 1995; Tossi et 


\begin{tabular}{|c|c|c|c|}
\hline Peptide & Sequence & Origin & Class \\
\hline LL-37/hCAP18 & LLGDFFRKSKEKIGKEFKRIVQRIKDFLRNLVPRTES & Man & $\alpha$-helical \\
\hline RL-37 & RLGNFFRKVKEKIGGGLKKVGQKIKDFLGNLVPRTAS & $\begin{array}{l}\text { Rhesus mon- } \\
\text { key }\end{array}$ & $\alpha$-helical \\
\hline CAP18 & GLRKRLRKFRNKIKEKLKKIGQKIQGLLPKLAPRTDY & Rabbit & $\alpha$-helical \\
\hline CRAMP & GLLRKGGEKIGEKLKKIGQKIKNFFQKLVPQPE & Mouse & $\alpha$-helical \\
\hline rCRAMP & GLVRKGGEKFGEKLRKIGQKIKEFFQKLALEIEQ & Rat & $\alpha$-helical \\
\hline CAP11 ${ }^{*}$ & (GLRKKFRKTRKRIQKLGRKIGKTGRKVWKAWREYGQIPYPCRI)2 & Guinea pig & $\alpha$-helical (dimeric) \\
\hline Canine cath & KKIDRLKELITTGGQKIGEKIRRIGQRIKDFFKNLQPREEKS & Dog & $\alpha$-helical \\
\hline Bac5 & RFRPPIRRPPIRPPFYPPFRPPIRPPIFPPIRPPFRPPLGPFP-NH2 & Cow & Linear, Pro-rich \\
\hline Bac7 & $\begin{array}{l}\text { RRIRPRPPRLPRPRPRPLPFPRPGPRPIPRPLPFPRPGPRPIPRPLPFPRPG- } \\
\text { PRPIPRPL }\end{array}$ & Cow & Linear, Pro-rich \\
\hline BMAP-27 & GRFKRFRKKFKKLFKKLSPVIPLLHL-NH2 & Cow & $\alpha$-helical \\
\hline BMAP-28 & GGLRSLGRKILRAWKKYGPIIVPIIRI-NH2 & Cow & $\alpha$-helical \\
\hline BMAP-34 & GLFRRLRDSIRRGQQKILEKARRIGERIKDIFR-NH2 & Cow & $\alpha$-helical \\
\hline Indolicidin & ILPWKWPWWPWRR-NH2 & Cow & Linear, Trp-rich \\
\hline Dodecapeptide & RLCRIVVIRVCR & Cow & Disulfide bridged \\
\hline Water buffalo cath & GLPWILLRWLFFR-NH2 & Water buffalo & Linear, Trp-rich \\
\hline OADode & RYCRIIFLRVCR & Sheep & Disulfide bridged \\
\hline SMAP-29 & RGLRRLGRKIAHGVKKYGPTVLRIIRIA-NH2 & Sheep & $\alpha$-helical \\
\hline SMAP-34 & GLFGRLRDSLQRGGQKILEKAERIWCKIKDIFR-NH2 & Sheep & $\alpha$-helical \\
\hline OaBac5 & RFRPPIRRPPIRPPFRPPFRPPVRPPIRPPFRPPFRPPIGPFP-NH2 & Sheep & Linear, Pro-rich \\
\hline OaBac6 & RRLRPRHQHFPSERPWPKPLPLPLPRPGPRPWPKPLPLPLPRPGLRPWPKPL & Sheep & Linear, Pro-rich \\
\hline OaBac7.5 & $\begin{array}{l}\text { RRLRPRRPRLPRPRPRPRPRPRSLPLPRPQPRRIPRPILLPWRPPRPIPRPQ- } \\
\text { IQPIPRWL }\end{array}$ & Sheep & Linear, Pro-rich \\
\hline OaBac11 & $\begin{array}{l}\text { RRLRPRRPRLPRPRPRPRPRPRSLPLPRPKPRPIPRPLPLPRPRPK- } \\
\text { PIPRPLPLPRPRPRRIPRPLPLPRPRPRPIPRPLPLPQPQPSPIPRPL }\end{array}$ & Sheep & Linear, Pro-rich \\
\hline ChBac5 & RFRPPIRRPPIRPPFNPPFRPPVRPPFRPPFRPPFRPPIGPFP-NH2 & Goat & Linear, Pro-rich \\
\hline eCATH-1 & KRFGRLAKSFLRMRILLPRRKILLAS & Horse & $\alpha$-helical \\
\hline eCATH-2 & KRRHWFPLSFQEFLEQLRRFRDQLPFP & Horse & $\alpha$-helical \\
\hline eCATH-3 & KRFHSVGSLIQRHQQMIRDKSEATRHGIRIITRPKLLLAS & Horse & $\alpha$-helical \\
\hline PR-39 & RRRPRPPYLPRPRPPPFFPPRLPPRIPPGFPPRFPPRFP-NH2 & Pig & Linear, Pro-rich \\
\hline Prophenin-1 & $\begin{array}{l}\text { AFPPPNVPGPRFPPPNFPGPRFPPPNFPGPRFPPPNFPGPRFPPPNFPGPPF- } \\
\text { PPPIFPGPWFPPPPPFRPPPFGPPRFP-NH2 }\end{array}$ & Pig & Linear, Pro-rich \\
\hline Prophenin-2 & $\begin{array}{l}\text { AFPPPNVPGPRFPPPNVPGPRFPPPNFPGPRFPPPNFPGPRFPPPNFPGPPF- } \\
\text { PPPIFPGPWFPPPPPFRPPPFGPPRFP-NH2 }\end{array}$ & Pig & Linear, Pro-rich \\
\hline Protegrin-1 & RGGRLCYCRRRFCVCVGR-NH2 & Pig & Two-disulfide bridged \\
\hline Protegrin-2 & RGGRLCYCRRRFCICV-NH2 & Pig & Two-disulfide bridged \\
\hline Protegrin-3 & RGGGLCYCRRRFCVCVGR-NH2 & Pig & Two-disulfide bridged \\
\hline Protegrin-4 & RGGRLCYCRGWICFCVGR-NH2 & Pig & Two-disulfide bridged \\
\hline Protegrin-5 & RGGRLCYCRPRFCVCVGR-NH2 & Pig & Two-disulfide bridged \\
\hline PMAP-23 & RIIDLLWRVRRPQKPKFVTVWVR & Pig & $\alpha$-helical \\
\hline PMAP-36 & GRFRRLRKKTRKRLKKIGKVLKWIPPIVGSIPLGC-NH2 & Pig & $\alpha$-helical \\
\hline PMAP-37 & GLLSRLRDFLSDRGRRLGEKIERIGQKIKDLSEFFQS & Pig & $\alpha$-helical \\
\hline
\end{tabular}

al., 1995), cattle (Del Sal et al., 1992; Storici et al., 1992; Zanetti et al., 1993; Scocchi et al., 1994; Skerlavaj et al., 1996; Scocchi et al., 1997), sheep (Bagella et al., 1995; Mahoney et al., 1995) and goats (Shamova et al., 1999) contain multiple cathelicidins and the mature peptides represent each of the structural classes mentioned above. The presence of at least one $\alpha$-helical cathelicidin peptide in every mammal investigated is significant and suggests that a cathelicidin of this type was the prototype from which the family differentially expanded, generating a variety of peptides in selected species by several rounds of gene duplication and rapid divergence of the peptide coding sequence. The differential expansion of the gene family and the marked diversification of the peptide coding regions in those mammals that contain multiple family genes may be connected with differential 
selective pressures from microbial pathogens, suggesting that cathelicidin peptides may evolve rapidly under the pressure of the microbial flora and species-specific environmental pathogens.

In addition to one typical cathelicidin, rabbits (Levy et al., 1993) and mice (Moscinski and Hill, 1995) also contain distantly related family members, denoted p15s and B9, respectively. Functional in vitro studies of rabbit $\mathrm{p} 15 \mathrm{~s}$ have shown that, unlike typical cathelicidin components, these proteins do not undergo processing with release of an active peptide and are not microbicidal per se (Zarember et al., 2002). However, they exhibit antibacterial synergy with both the bactericidal/permeability-increasing protein (BPI) and the rabbit cathelicidin peptide CAP18 (Zarember et al., 2002). This activity, together with their location in the secondary granules of neutrophils, points to a role of $\mathrm{p} 15 \mathrm{~s}$ in potentiating neutrophil antimicrobial activity following degranulation.

A few cathelicidin-related sequences have recently been identified in other vertebrates including chicken (Lynn et al., 2004), rainbow trout (GenBank accession number AX812046), hedgehog skate (Leucoraja erinacea) (GenBank accession number CV222467) and the primitive vertebrate Atlantic hagfish (Myxine glutinosa) (Basanez et al., 2002, Uzzell et al., 2003). Those from hagfish are the most ancient and their propiece shows very limited sequence similarity to the mammalian cathelin propiece. However there are a few distinctive features that place the hagfish molecules within the cathelicidin protein family. For instance, the spacing of the four characteristic cysteine residues in the propiece is fairly well preserved, and a conserved F-x-[IV]-X-E-T$x-C-x(10)-C$ stretch that includes 2 of 4 cysteine residues of the proregion is present in the hagfish as well as the skate, chicken and trout sequences, and in most of the mammalian cathelicidins.

\section{Tissue distribution}

All mammalian cathelicidins were initially recognized as neutrophil-specific constituents. Their relative abundance in these cells varies between and within species. The amount of the hCAP18/LL-37 in neutrophils, for instance, is $0.627 \mu \mathrm{g}$ protein per $10^{6}$ cells (Sorensen et al., 1997a) whereas the bovine cathelicidins Bac5 and Bac7 account for at least $2 \mu \mathrm{g}$ each per $10^{6}$ cells in the bovine neutrophils (Zanetti et al., 1991). Based on comparative Northern analysis of bovine bone marrow cells, substantially lower amounts of BMAPs are present in the same cells (unpublished observations).

The cathelicidin storage organelles in neutrophils are secretory granule subsets (Zanetti et al., 1991; Nagaoka et al., 1997; Sorensen et al., 1997b) that can be readily mobilized upon inflammatory or infectious stimuli and rapidly discharge their contents extracellularly (Zanetti et al., 1991; Panyutich et al., 1997; Sorensen et al., 2001) or in phagocytic vacuoles (Zanetti et al., 1991; Sorensen et al., 2001). However, hCAP18/LL-37 is produced in other types of leukocytes, in skin and in various epithelia (Table 2 ), as will be discussed later in this chapter. Mouse CRAMP (mCRAMP) also has a broad tissue distribution. In addition to myeloid cells, mCRAMP is produced in the skin, testis, spleen and digestive tract of mice (Gallo et al., 1997) and rat CRAMP (rCRAMP) is detected in the thymus, lung, oral cavity, digestive tract and testis (Termen et al., 2003) (Table 2). In those mammals, where multiple cathelicidin genes are present, there appear to be differences in the pattern of expression of distinct family members, which could be connected with a diversified biological role of these molecules. For instance, RT-PCR of bovine cells and tissues indicates that the genes encoding proline-rich cathelicidin peptides are expressed in bovine marrow cells and lymphoid organs (Tomasinsig et al., 2002) and those encoding $\alpha$-helical and cysteine-containing peptides are further detected in tongue, mammary gland, vagina and testis (Tomasinsig, unpublished observations) (Table 2).

\section{Genes and biosynthesis}

\section{Gene structure}

Cathelicidin genes are approximately $2 \mathrm{~kb}$ in size and show a conserved four- exon/three-intron organization (Zhao et al., 1995a,b; Gudmundsson et al., 1995; Gudmundsson et al., 1996; Larrick et al., 1996; Scocchi et al., 1997; Huttner et al., 1998). Exons 1 to 3 specify the signal peptide and the cathelin propiece and the exon 4 region contains the processing site, the antimicrobial domain-coding sequence and the 3'UTR (Fig. 1). Generally, the 5' moieties of cathelicidin genes are much more related in sequence than the regions corresponding to the antimicrobial peptides. In mammals where more than one gene is present, conservation of the 5' region is higher from intra- than interspecies comparisons at both the exon and intron levels. Porcine gene pairs, for instance, can reach higher than $99 \%$ sequence identity in the region encompassing the 5' UTR, exons 1 to 3 and

\begin{tabular}{|l|l|l|}
\hline \multicolumn{2}{|l|}{ Table 2. Cell- and tissue-specific expression of selected cathelicidin peptides } \\
\hline \multirow{2}{*}{ Cathelicidin } & Expression & \multicolumn{2}{|l|}{} \\
\cline { 2 - 3 } & Constitutive & Inducible \\
\hline LL-37 & $\begin{array}{l}\text { Immature neutrophils, monocytes, mast cells, NK, B, T } \\
\text { cells, newborn skin, epithelia of the respiratory, digestive } \\
\text { and reproductive tracts, eccrine and salivary glands }\end{array}$ & $\begin{array}{l}\text { Keratinocytes (inflammation, injury, infection), intestinal } \\
\text { epithelial cells (dietary substrates, cell differentiation), synovial } \\
\text { membrane and nasal mucosa (inflammation) }\end{array}$ \\
\hline CRAMP & $\begin{array}{l}\text { Immature neutrophils, spleen, respiratory and intestinal } \\
\text { epithelia, newborn skin, testis }\end{array}$ & Keratinocytes (injury, infection) \\
\hline PR-39 & Immature neutrophils, lymphoid organs (piglets) & Bone marrow cells (bacteria, LPS, IL-6, retinoic acid) \\
\hline Bac5 & Immature neutrophils, lymphoid organs & Peripheral neutrophils (bacteria, LPS) \\
\hline $\begin{array}{l}\text { Dodecapeptide } \\
\text { and BMAPs }\end{array}$ & $\begin{array}{l}\text { Immature neutrophils, lymphoid organs, tongue, mammary } \\
\text { gland, reproductive tract }\end{array}$ & Not determined \\
\hline
\end{tabular}


introns 1 to 3 (Zhao et al., 1995b), most likely reflecting the occurrence of specific gene conversion events that contribute to the sequence homogeneity in this region.

\section{Chromosomal localization}

The conserved structural organization of the genes and the high sequence identity of the 5 ' regions support the concept that all mammalian cathelicidins arose from the same gene precursor. Further evidence for a common origin is provided by adjacent chromosomal location of multiple cathelicidin genes in cattle (Castiglioni et al., 1996), sheep (Huttner et al., 1998) and pigs (Zhao et al., 1995a,b), as revealed by genomic sequencing and chromosomal mapping studies. Eleven cathelicidin genes cluster to the same region on bovine chromosome 22q24, thereby defining a locus that has been referred to as CATHL@ (Castiglioni et al., 1996; Scocchi et al., 1997), and an eight-member gene cluster has been mapped to sheep chromosome 19 (Huttner et al., 1998). The number of distinct genes (Gudmundsson et al., 1995; Zhao et al., $1995 a, b)$ and cDNAs identified in pigs indicates that the porcine cathelicidin family is comparable in size to that of cattle. In striking contrast with the high abundance of human beta defensin (hBD) genes (Scheetz et al., 2002), only one cathelicidin gene (CAMP) has been detected in humans. $C A M P$ has been localized to human chromosome 3 (Gudmundsson et al., 1995), which is homologous to mouse chromosome 9 and pig chromosome 13, where the genes encoding mCRAMP $(C n / p)$ and PR-39 have been mapped respectively in mice and pigs.

\section{Biosynthesis and activation}

Detailed studies of the biosynthesis and biological processing of the neutrophil cathelicidins have been performed in humans (Sorensen et al., 2001), cows (Zanetti et al., 1990) and pigs (Panyutich et al., 1997). The biosynthetic window for these molecules in bone marrow cells is restricted to the myelocyte/metamyelocyte stage of neutrophil maturation. Similar to defensins, cathelicidins are synthesized in a prepropeptide form including signal peptide, propiece and C-terminal peptide (Fig. 1), but unlike the neutrophil $\alpha$ defensins, which are fully processed to mature peptides before storage in the azurophil granules (Yount et al., 1999), cathelicidins are targeted as propeptides to the specific granules (Cowland et al., 1995; Nagaoka et al., 1997; Sorensen et al., 1997b) or to a distinct granule subset present in the bovine neutrophils called large granules (Zanetti et al., 1990). No constitutive expression of cathelicidins has been detected in adult mammals following release of neutrophils into the bloodstream. The neutrophil granule storage form of cathelicidins is not microbicidal (Scocchi et al., 1992; Zaiou et al., 2003) because an additional processing step, involving cleavage in the region that joins the cathelin and the C-terminal domain, is required to unmask the antimicrobial activity. This processing step is mediated by elastase in cows and pigs. The requirement of elastase for the bovine and porcine cathelicidins has been determined based on in vitro (Scocchi et al., 1992; Panyutich et al., 1997) and in vivo (Cole et al., 2001) processing studies and has been confirmed by the presence of elastase-specific cleavage residues at the peptide/cathelin boundary in the propeptide sequences (Zanetti et al., 1995). In humans, activation of neutrophil-derived hCAP18/LL-37 is carried out by a different serine protease, i.e., proteinase 3 (Sorensen et al., 2001), as will be described in more detail later. Both elastase and proteinase 3 are conveniently stored in a separate compartment, the azurophil granules, which prevents unwanted intracellular processing of cathelicidin molecules to active antimicrobial peptides in resting neutrophils. Processing studies of the bovine (Zanetti et al., 1991) and porcine (Panyutich et al., 1997) cathelicidins have shown that the mobilization of secondary/large and azurophil granules leads to coincident release of the granule contents either in the extracellular milieu (Zanetti et al., 1991; Panyutich et al., 1997) or in phagocytic vacuoles (Zanetti et al., 1991) and this in turn results in rapid and efficient generation of functionally active cathelicidin peptides, further indicating that the biological processing mediated by the neutrophilic serine proteases is an effective means to control peptide activation.

\section{Regulation of cathelicidin biosynthesis}

Besides expression in the neutrophil precursors, some cathelicidin genes show constitutive and/or inducible expression in various cells and tissues (Table 2). Their tissue-specific expression is regulated by microbial, inflammatory and developmental stimuli. The molecular mechanisms of gene regulation, however, are largely unexplored.

The hCAP18/LL-37 gene is induced in keratinocytes exposed to $S$. aureus (Midorikawa et al., 2003) and the CRAMP-encoding gene is upregulated in mouse skin in response to subcutaneous inoculation of Group $A$ Streptococcus (Dorschner et al., 2001). Induction of PR39 and protegrin gene expression in porcine bone marrow cells (Wu et al., 2000) and of Bac5 gene expression in bovine peripheral neutrophils (Tomasinsig et al., 2002) has been observed following cell activation with bacteria or purified LPS.

Both the hCAP18/LL-37 and mCRAMP genes are upregulated in response to sterile incision of the skin (Dorschner et al., 2001). Interestingly, only insulin-like growth factor I (IGF-I), a molecule involved in tissue regeneration after wounding, among other growth factors (TGF- $\alpha$, TGF- $\beta 1$, bFGF) and proinflammatory cytokines (IL-1 $\beta$, IL-6, TNF- $\alpha$ ), elicits expression of hCAP18/LL-37 in cultured human keratinocytes (Sorensen et al., 2003a), suggesting a role for this growth factor in hCAP18/LL-37 expression upon injury. Conversely, hBD-2 and hBD-3 are induced in cultured keratinocytes by IL-1 $\beta$ and TGF$\alpha$, respectively, but not by IGF-I (Sorensen et al., 2003a), possibly indicating that these cells respond to different stimuli with distinct patterns of antimicrobial peptide expression. As opposed to hBDs (Liu et al., 2002; Liu et al., 2003; Tsutsumi-Ishii and Nagaoka 2003), no evidence has been produced to date for direct induction of hCAP18/ LL-37 by proinflammatory cytokines. Both hCAP18/LL-37 and hBD2 genes are underexpressed in atopic dermatitis (Ong et al., 2002), but only the defensin defect has been explained in a recent report based on insufficient amounts 
of TNF- $\alpha$ and INF- $\gamma$ in this disease (Nomura et al., 2003). The reason for the under-representation of hCAP18/LL37 still needs to be explained.

Cathelicidin synthesis is also connected with the state of cell differentiation. This is illustrated by human colon epithelium that shows constitutive expression of the hCAP18/LL-37 gene coincident with epithelial cell differentiation (Hase et al., 2002; Schauber et al., 2003). Notably, no changes in the expression levels of this gene are observed in inflamed colon (Hase et al., 2002) or in colonic epithelial cell lines stimulated by IL-1 $\alpha$, TNF$\alpha$, LPS, PMA or other proinflammatory mediators such as IFN- $\gamma$, IFN- $\alpha$ and IL-6 (Hase et al., 2002; Schauber et al., 2003). Expression of hCAP18/LL-37, however, is stimulated by butyrate and other dietary short chain fatty acids that are known to induce differentiation of human colon cells (Schauber et al., 2003). The possible involvement of the MEK-ERK intracellular signal pathway is suggested by the observation that MEK inhibition blocks hCAP18/LL-37 induction by butyrate, while enhancing butyrate-dependent cell differentiation. Conversely, inhibition of MAP kinase p38 does not affect butyratestimulated hCAP18/LL-37 induction, but inhibits butyratedependent epithelial differentiation (Schauber et al., 2003), thus suggesting that butyrate-induced epithelial cell differentiation and hCAP18/LL-37 expression in colon are mediated by distinct signaling pathways that are both activated by butyrate.

The MCRAMP and PR-39 appear to be regulated developmentally (Gallo et al., 1997; Wu et al., 1999), since the CRAMP transcript is detected early during embryogenesis and PR-39 is expressed in bone marrow and in various organs in piglets up to the first post-natal days and only in marrow cells afterwards.

Inducible expression of PR-39 by interleukin 6 or retinoic acid is observed in porcine bone marrow cells ( $\mathrm{Wu}$ et al., 2000), in keeping with the presence of consensus sites/response elements for nuclear factors dependent on these signals in the gene promoter region. Indeed, putative consensus sites for binding to transcription factors involved in hematopoiesis, inflammation and acute phase reaction, such as nuclear factor-interleukin 6 , nuclear factor- $\mathrm{B}$, acute phase-response factor and gamma-interferon response element, are present within a few hundred basepairs in the 5' flanking sequences of effectively all sequenced cathelicidin genes, indicating the potential to respond to signals from inflammatory and infectious stimuli. However, in general, very little information is available on the intracellular mechanisms involved in cathelicidin gene regulation. A deeper understanding of this aspect of the biology of cathelicidins is essential to clarify the role of cathelicidins in health and disease.

\section{The cathelin domain: an unsolved puzzle}

Several reportsindicatethatalthoughdevoid ofindependent antimicrobial activity, unprocessed cathelicidins (i.e., the propeptides) may increase the antimicrobial potency of other (poly)peptides and/or exert separate host defense activities. Some of the bovine cathelicidin propeptides, for instance, inhibit in vitro the activity of cathepsin L, as will be discussed shortly, and studies of the bovine cathelicidin proBac7 indicate that this propeptide is a chemoattractant in vitro for monocytes, with a dosedependent, bell shaped response and optimal activity at $10-9$ M (Verbanac et al., 1993). Although reported much earlier than similar activities in other peptides, the molecular mechanism of this chemotactic activity has not been investigated in depth, although it certainly involves the cathelin portion of proBac7 since the mature Bac7 peptide has no effect on the migration of monocytes (Verbanac et al., 1993). Unprocessed rabbit cathelicidin proCAP18 exhibits antibacterial synergy with antimicrobial peptides and polypeptides and displays endotoxinneutralizing activity independent of the presence of other defense molecules at sub-nanomolar concentrations. The latter activity cannot be attributed to the C-terminal peptide domain since the propeptide is 100 -fold more potent, on a molar basis, than the mature peptide CAP18 (Zarember et al., 2002). These findings strongly suggest that structural determinants within the cathelin domain of cathelicidins can make contributions to host defense independent of the C-terminal domain. Evidence for an autonomous function of cathelin has been provided by the reported ability of the recombinant hCAP18 cathelin domain to inhibit bacterial growth in vitro (Zaiou et al., 2003). An interesting implication of this finding is that the holoprotein hCAP18/LL-37, which does not display autonomous antimicrobial properties, is processed to generate two distinct antimicrobial peptides, cathelin and LL-37. Recombinant cathelin is active against $S$. aureus and S. epidermidis (MIC of $32 \mu \mathrm{M}$ ), which are resistant to LL-37 under the same in vitro conditions, and so the two peptides seem to exert complementary antibiotic activities (Zaiou et al., 2003). It remains to be clarified how human cathelin exerts this bactericidal effect. The mechanism of action likely differs from that of classical antimicrobial peptides in that the cathelin sequence has no net positive charge and its overall structure does not match that of typical antimicrobial peptides.

In addition to a possible direct antimicrobial activity, human cathelin inhibits the activity of cathepsin $L$ in vitro (Zaiou et al., 2003). This feature is shared with the bovine propeptides (Verbanac et al., 1993; Storici et al., 1996) and can be explained based on structural considerations. The cathelin domain has a sequence of approximately 100 residues, including four cysteine residues at conserved positions that form two disulfide bonds in the $1-2,3-4$ arrangement. Besides high levels of identity among cathelicidin family members, a moderate (less than $40 \%$ ) sequence similarity is shared with members of the cystatin family of cysteine proteinase inhibitors, both at the protein (Ritonja et al., 1989; Storici et al., 1996) and the gene (Scocchi et al. 1997; Zanetti et al., 2000) levels. Furthermore, the X-ray structure of the cathelin domain of the porcine cathelicidin protegrin-3 shows an overall fold similar to that of chicken cystatin (Sanchez et al., 2002), and although significant differences in the detailed structures, particularly in the vicinity of loop regions, have been revealed by the corresponding solution structures (Yang Y. et al., 2003), these differences do not affect the global cystatin-like fold. Based on these considerations, a certain degree of functional similarity between the two families is reasonably expected. Like human cathelin, 
cystatin members display in vitro antibacterial activity that is independent of cysteine proteinase inhibition (Blankenvoorde et al., 1998; Hamil et al., 2002).

The degree of evolutionary divergence between the cystatin and cathelicidin families can be inferred from studies of the cystatin-like activities of cathelicidins. Bovine cathelicidin components inhibit the activity of cathepsin L in vitro, but do not affect the activity of papain, although both papain and cathepsin $\mathrm{L}$ are highly susceptible to cystatins (Verbanac et al., 1993; Storici et al., 1996). Also, the concentrations required for cathepsin $L$ inhibition are much higher for cathelicidins ( $\mathrm{K}_{\mathrm{i}}$ values in the $10-{ }^{7}$ to $10{ }^{8}$ $M$ range) than for cystatins ( $K_{i}$ values of $10-{ }^{10}$ to $10-{ }^{12}$ $\mathrm{M})$, likely due to the absence in cathelicidins of important determinants required for binding to cathepsin $L$, such as a conserved Gly at the N-terminus and the QXVXG binding motif of cystatins. These differences have raised an issue concerning the in vivo relevance of the inhibitory effect of cathelicidins. Cathelin levels compatible with in vitro inhibitory concentrations can be reached at inflammatory sites, due to massive recruitment and activation of neutrophils and subsequent extracellular release and processing of cathelicidins. This could lead to local accumulation of cathelin to levels sufficient for protection from the destructive potential of cathepsin L. This enzyme is a major secretion product of macrophages and recent evidence indicates that epithelial-derived $\beta$ defensins and the antiprotease/antimicrobial protein SLPI are among the molecules that are susceptible to its proteolytic effects (Taggart et al., 2003). The inhibitory properties of extracellularly released cathelin suggest that this protein is well suited to prevent antimicrobial peptide degradation by cathepsin $L$, once it is released in the extracellular milieu during inflammation.

Further roles have been suggested for the cathelin propiece, mostly based on structural considerations. The sequence is generally negatively charged and may thus interact with the positively charged C-terminal peptide. The resulting configuration could have implications for folding of the polypeptide or may help in preventing unwanted membrane interactions prior to granule mobilization. These putative activities, however, are not supported by experimental evidence and the validity of these hypotheses remains to be tested.

Although the exact role of the cathelin propiece is still debated and the in vitro effects of cathelin await further characterization and validation in animal models, the strong evolutionary pressure for sequence conservation is a clear indication of an essential role of this domain.

\section{The human cathelicidin hCAP18/LL-37}

Humans and primates each contain only one cathelicidin family member, with $86 \%$ overall sequence identity $(68 \%$ in the 37-residue peptide region) between Rhesus and man (Zhao et al., 2001).

The human cathelicidin was independently identified in 1995 by three groups; it was deduced from myeloid bone marrow cDNA (Agerberth et al., 1995; Cowland et al., 1995; Larrick et al., 1995) and isolated from neutrophils (Cowland et al., 1995). The name hCAP18 refers to the predicted mass of the full-length polypeptide (approximately $18 \mathrm{kDa}$ ) and the cationic character of the
C-terminal sequence ( $\underline{\text { Cationic }}$ Antimicrobial Peptide) and implicitly recognizes its similarity to the rabbit cathelicidin CAP18. The alternative designation "FALL-39" was used originally on the assumption that Phe-Ala-Leu-Leu (FALL) were the $\mathrm{N}$-terminal residues of the putative antimicrobial domain. The name was then changed to LL-37 when the antimicrobial peptide was isolated from neutrophils and found to consist of 37 residues, with Leu-Leu at the Nterminus (Gudmundsson et al., 1996). The term hCAP18 is currently accepted to indicate the propeptide, whereas LL-37 denotes the peptide liberated from the holoprotein.

\section{Sites of expression}

hCAP-18/LL-37 is produced in immature neutrophils (Sorensen et al., 1997) and in various blood cells populations that are involved in inflammatory and immune responses, including NK cells, $\gamma \delta \mathrm{T}$ cells, B cells, monocytes (Agerberth et al., 2000) and mast cells (Di Nardo et al., 2003), as well as in hematopoietic cell lines and human leukemia cells (Yang Y.H. et al., 2003). In addition, this gene is widely expressed in skin, in the squamous epithelia of the airways, mouth, tongue, esophagus, intestine, cervix and vagina (Frohm Nilsson et al., 1999; Bals et al., 1998; Hase et al., 2002), in sweat and salivary glands (Murakami et al., 2002a, b) and in epididymis and testis (Agerberth et al., 1995; Malm et al., 2000; Hammami-Hamza et al., 2001). The polypeptide is secreted in human wound fluid (Frohm et al., 1996) and airway surface fluid (Bals et al., 1998) and is detected in intriguingly high amounts (85 $\mu \mathrm{g} / \mathrm{ml}$ on average) in seminal plasma (Andersson et al., 2002). Additionally, hCAP18/LL-37 has been detected at approximately $20 \mu \mathrm{g} /$ $\mathrm{ml}$ in tracheal aspirates of newborns (Schaller-Bals et al., 2002), and in vernix caseosa and skin during the perinatal period (Marchini et al., 2002; Dorschner et al., 2003). The synergistic antimicrobial activity of LL-37 and hBD-2 and efficient killing of Group B Streptococcus, an important neonatal pathogen (Dorschner et al., 2003), suggest that these peptides provide vicarious defense functions during development of cellular immune response mechanisms in the newborn period. It is interesting to note that hCAP18/ LL-37 and other human antimicrobial peptides, including $\beta$-defensins, often show overlapping tissue distribution. In some cases, different regional distributions and induction signals have been described (Hase et al., 2002), suggesting that these peptides occupy distinct functional niches and may be called into play in response to distinct stimuli within the same tissue.

\section{Processing}

Investigations of the physiological processing of the myeloid-derived hCAP18 indicate that the propeptide is cleaved to generate the antimicrobial peptide LL-37 in exocytosed material from neutrophils (Sorensen et al., 2001). Conversely, cleavage is not detected in phagocytic vacuoles, despite both hCAP18 and azurophil granule proteins being detected inside the vacuoles and despite the fact that all known azurophilic serine proteases, including elastase, proteinase 3 and cathepsin G, can cleave hCAP18 in vitro. Experimental evidence has shown that among these enzymes, proteinase 3 is solely responsible for processing the propeptide after exocytosis 
(Sorensen et al., 2001). This result correlates with the presence of a proteinase 3-compatible (Ala-Leu) cleavage site, as deduced from cDNA, between the cathelin portion and the antimicrobial domain of hCAP18. Instead, a typical (Val-Arg) elastase cleavage site is predicted at the cathelin/peptide boundary of most porcine and bovine cathelicidins. These findings suggest that cathelicidins are processed by distinct enzymes in related species. Further studies of the human cathelicidin have shown timely cleavage of epididymal-derived hCAP18 in seminal plasma by the prostate-derived protease gastricsin (pepsin C) in the presence of vaginal fluid at low $\mathrm{pH}$, generating a cathelin protein and a functionally active ALL-38 (38 amino acid residues) (Sorensen et al., 2003b). These studies provide evidence that cathelicidins are processed differently in different physiological contexts within the same organism. Since activation of the prostate-derived gastricsin requires the low $\mathrm{pH}$ of the vagina, processing of epididymal hCAP18 to ALL-38 likely takes place after sexual intercourse and may represent a mechanism to prevent infection after coitus. This hypothesis is further supported by the presence of various other antimicrobial proteins and peptides in the male reproductive tract (Yenugu et al., 2003), including defensin members (Com et al., 2003). Cystatin family members are also found in the male reproductive tract (Shoemaker et al., 2000; Hamil et al., 2002) and have been suggested to modulate cathepsin activities related to sperm development and maturation. The epididymal-derived cystatin 11, for instance, binds the surface of sperm (Hamil et al., 2002), as does hCAP18/LL-37 (Malm et al., 2000). In this context, since hCAP18/LL-37 is expressed in testis (Agerberth et al., 1995; Hammami-Hamza et al., 2001) and epididymis (Malm et al., 2000) and is released in seminal plasma (Malm et al., 2000), it would be interesting to investigate the potential of human cathelin to modulate the activity of cathepsin L, which is known to play an important role in spermatogenesis (Wright et al., 2003).

It is not known whether other proteases may be involved in processing of hCAP18 in the numerous tissues where hCAP18 and/or the mature LL-37 have been detected.

The role and fate of hCAP18/LL-37 have proven elusive in some instances. Relatively high levels of uncleaved hCAP18 are present in plasma (approximately $1.2 \mu \mathrm{g} / \mathrm{ml}$, Sorensen et al., 1997a), where the propeptide circulates bound to lipoproteins through the antimicrobial domain (Wang et al., 1998; Sorensen et al., 1999). Based on their association with hCAP18, the plasma lipoproteins have been suggested to be a reservoir of LL-37 in blood, but the precise destination and metabolic fate of the lipoprotein-associated hCAP18/LL-37 has not been elucidated. The presence of uncleaved hCAP18 in blood may be explained by the need for protection from potential cytotoxic effects of mature LL-37. Alternatively, the cathelin domain may protect the peptide from proteolytic degradation in protease-rich media, although both the mature LL-37 and the holoprotein have been shown to be degraded in vitro and ex vivo in human wound fluid by elastase-producing $P$. aeruginosa (Schmidtchen et al., 2002). Most intriguing is the persistence of uncleaved hCAP18 in infection/inflammatory settings, since one should definitely expect to detect the biologically active form in these environments. The holoprotein, for instance, is found in the phagocytic vacuoles of activated neutrophils (Sorensen et al., 1997b), in wound and blister fluids (Frohm et al., 1996) and in psoriatic skin (Ong et al., 2002). The accumulation of uncleaved propeptide in these settings lends credence to the functional significance of this molecule and encourages further functional studies of the propeptide.

\section{Antimicrobial and cytotoxic activities}

The antimicrobial peptide LL-37 corresponds to the 37 residue $\mathrm{C}$-terminal region of hCAP18 and shows a net charge of +6 at neutral $\mathrm{pH}$. It belongs to the group of membrane-active, amphipathic $\alpha$-helical peptides with wide spectrum activity. Under laboratory assay conditions, this peptide inhibits the growth of a variety of Gram-negative ( $P$. aeruginosa, S. typhimurium, $E$. coli) and Gram-positive (S. aureus, S. epidermidis, L. monocytogenes and vancomycin -resistant enterococci) species in the micromolar and sub-micromolar range of peptide concentrations (Turner et al., 1998). LL-37 is active against clinically important strains of Gramnegative uropathogens ( $E$. coli HU734, $P$. aeruginosa AK1, K. pneumoniae 3a) (Smeianov et al., 2000), periodontal (Actinobacillus actinomycetemcomitans, Capnocytophaga, Porphyromonas and Prevotella spp.) (Tanaka et al., 2000; Isogai et al., 2003) and common wound pathogens (Group A Streptococcus) (Dorschner et al., 2001). The high amounts of LL-37 detected in airway epithelial cells during infection (Schaller-Bals et al., 2002) and especially in psoriatic skin lesions (approximately 304 $\mu \mathrm{M}$, Ong et al., 2002), suggest that the concentrations of LL-37 that are effective in vitro are fully compatible with those found in vivo. Furthermore, the in vitro antimicrobial activity is enhanced in the presence of $\alpha$ or $\beta$ defensins (Ong et al., 2002; Nagaoka et al., 2000) further suggesting that these peptides synergize under in vivo conditions to form an efficient barrier against microbial invasion. Unlike most defensin members, LL-37 is active against several bacteria in high salt media (up to $150 \mathrm{mM} \mathrm{NaCl}$ ) (Turner et al., 1998; Nagaoka et al., 2000), supporting its capacity to function under a variety of physiological conditions. Fungal species of Candida appear to be resistant to LL-37 (Turner et al., 1998) but tripomastigotes of the protozoan parasite $T$. cruzi and peripheral blood leukocytes are susceptible in vitro to 13-25 $\mu \mathrm{M}$ peptide concentrations (Johansson et al., 1998), indicating that LL-37 is not highly selective to prokaryotic cells. The cytotoxic activity is inhibited by the presence of serum (Johansson et al., 1998) suggesting that serum components provide a physiological mechanism to protect blood cells from potentially harmful effects of the peptide.

\section{Mechanisms of antimicrobial activity}

Whereas most $\alpha$-helical antimicrobial peptides show a transition from an unordered state in aqueous solutions to an $\alpha$-helical structure in membrane-mimicking conditions, LL-37 adopts an $\alpha$-helical structure in physiological buffer conditions and remains helical upon association with the membrane (Johansson et al., 1998). The stability of the helix has been attributed to peptide concentration- 
dependent aggregation induced by ionic and hydrophobic interactions that are favored by the presence of negatively charged residues and a short hydrophobic N-terminal region in the LL-37 sequence (Oren et al., 1999). The extent of helicity correlates with the antibacterial activity of LL-37 against both Gram-negative and Gram-positive bacteria (Johansson et al., 1998), indicating that this conformation is an important requirement for activity. The helical LL-37 kills target organisms by disrupting membrane integrity (Turner et al., 1998). Biophysical measurements using model systems (Johansson et al., 1998; Oren et al., 1999; Henzler Wildman et al., 2003) indicate that the membrane disruption mechanism involves orientation of the amphipathic helix parallel to the surface of both anionic and zwitterionic bilayers. The peptide accumulates on the membrane in a carpet-like fashion and induces leakage (Oren et al., 1999; Henzler Wildman et al., 2003), possibly through formation of toroidal peptide-lipid pores, as suggested by combined solid state NMR and differential scanning calorimetry studies (Henzler Wildman et al., 2003) that show a peptide-induced positive curvature strain in lipid bilayers. LL-37 is less disruptive in this study to lipids with choline headgroups, consistent with a protective role for choline headgroups against the membrane perturbing effects of LL-37 (Henzler Wildman et al., 2003). This observation supports bacterial resistance studies indicating that addition of choline headgroups to lipopolysaccharide in the outer membrane contributes to resistance of $H$. influenzae to killing by LL-37 (Lysenko et al., 2000).

\section{Other activities}

Recent work has brought into the spotlight the multifunctional nature of LL-37 (Table 3). In addition to direct microbial killing, LL-37 binds free LPS in vitro with high affinity (Turner et al., 1998), sharing this property with many other antimicrobial peptides, and inhibits LPSinduced cellular responses such as release of TNF- $\alpha$, nitric oxide and tissue factor, $\mathrm{PGE}_{2}, \mathrm{MCP}-1$ and MIP-2 (Hirata et al., 1994; Larrick et al., 1994; Larrick et al., 1995; Ohgami et al., 2003). Additionally, LL-37 prevents macrophage activation by lipoteichoic acid and noncapped lipoarabinomannan (Scott et al., 2002), suggesting that it binds various bacterial components in vivo.

There are clear data to show that LL-37 also interacts with host cells to mediate various host defense responses (Table 3 and Fig. 2). LL-37 is chemotactic in vitro, inducing selective migration of human peripheral blood monocytes, neutrophils and CD4 T cells (Agerberth et al., 2000; De Yang et al., 2000) with a dose-dependent, bell shaped response at optimal concentrations ranging from $10-{ }^{5}$ to $10-{ }^{7} \mathrm{M}$. Whereas the antimicrobial and cytotoxic activities are mediated by membrane perturbation and are serum- sensitive (Johansson et al., 1998), the chemotactic activity of LL-37 is largely unaffected by serum and depends on binding to formyl peptide receptor-like 1 (FPRL1), a G protein-coupled receptor (De Yang et al., 2000). The latter finding suggests that LL-37 contributes to immune responses by participating in the recruitment of inflammatory and immune cells that express functional FPRL1. However, as the chemotactic concentrations of LL-37 are higher than those of classical chemokines, cellular recruitment by LL-37 may be active only when a threshold LL-37 concentration is reached following upregulation of the gene in epithelial cells and/or massive release from accumulating neutrophils.

LL-37 has been reported to attract rat peritoneal mast cells with an optimal concentration of $5 \mu \mathrm{g} / \mathrm{ml}$, apparently through a receptor/s other than FPRL1, and to induce histamine release and intracellular $\mathrm{Ca}^{2+}$ mobilization in these cells (Niyonsaba et al., 2003). These activities of LL-37 highlight the potential involvement of this peptide in mast cell recruitment at inflammatory sites, where these cells are known to contribute to site-specific inflammation by phagocytosing opsonized bacteria and through neutrophil recruitment. LL-37-induced degranulation of mast cells leads to release of inflammatory mediators including histamine, which favors neutrophil infiltration into inflamed tissues by increasing vascular permeabilization. Investigations of the effects of LL-37 on mast cells however have been limited to rat mast cells and require confirmation using human mast cells.

Further evidence for involvement of LL-37 in modulating host cell responses comes from microarraybased studies indicating that LL-37 alters transcriptional responses in the human lung carcinoma cell line A549 and the murine macrophage cell line RAW 264.7. Numerous genes, including antiinflammatory and proinflammatory genes, are up/down-regulated in these cells in response to $50-100 \mu \mathrm{g} / \mathrm{ml}$ of LL-37. Among the genes that are upregulated are those encoding chemokines and chemokine receptors (Scott et al., 2002), suggesting that LL-37 may indirectly amplify cell recruitment through modulation of gene expression in target cells.

A regulatory function of LL-37 in the antimicrobial and inflammatory response of the airway epithelium is also suggested by the finding that LL-37 activates primary bronchial epithelial cells and the lung carcinoma cell line $\mathrm{NCl}-\mathrm{H} 292$, possibly via activation of a cell surface metalloproteinase that would then process membraneanchored epidermal growth factor receptor (EGFR) ligands. These in turn would activate the EGFR, leading to activation of the extracellular signal-regulated kinase (ERK)1/2 and gene transcription (Tjabringa et al., 2003).

In addition to its capability to augment host defenses via these activities, LL-37 could play a role in repair of

Table 3. Biological activities of selected cathelicidin peptides

\begin{tabular}{|c|c|c|}
\hline LL-37 & PR-39 & BMAP28 \\
\hline $\begin{array}{l}\text { Antimicrobial activity } \\
\text { Binding and inactivation of LPS } \\
\text { Chemotaxis of blood cells } \\
\text { Activation of epithelial cells Histamine release } \\
\text { from mast cells } \\
\text { Induction of angiogenesis Modulation of gene } \\
\text { expression Re-epithelialization of skin }\end{array}$ & $\begin{array}{l}\text { Antimicrobial activity Chemotaxis of neutrophils } \\
\text { Inhibition of NADPH oxidase activity } \\
\text { Induction of angiogenesis Inhibition of IkBa deg- } \\
\text { radation Induction of syndecan expression } \\
\text { Inhibition of macrophage apoptosis }\end{array}$ & $\begin{array}{l}\text { Antimicrobial activity } \\
\text { LPS binding and inactivation Apoptosis of } \\
\text { hematopoietic and fibroblast-derived cells }\end{array}$ \\
\hline
\end{tabular}




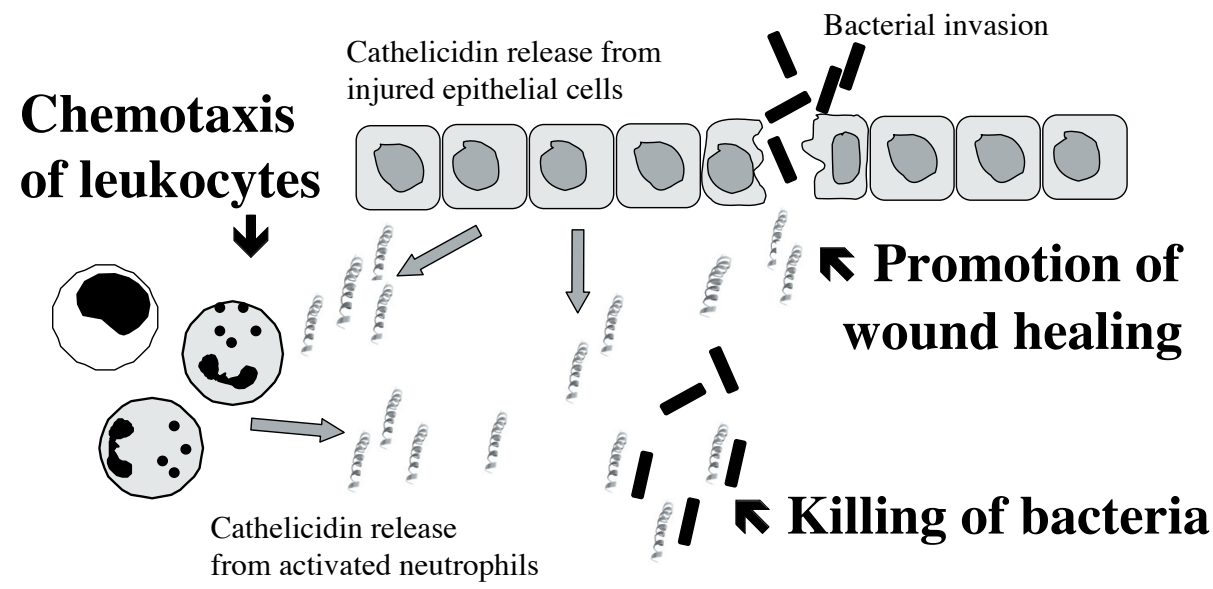

Fig. 2. Biological activities of the human cathelicidin LL-37 at epithelial surfaces. hCAP18 is synthesized and released from epithelial cells in response to microbial or physical injury. The holoprotein is processed to produce the $\alpha$-helical peptide LL-37 and the cathelin propiece. LL-37 participates in the recruitment of neutrophils and other circulating cells at sites of infection. Release of hCAP18 from the cytoplasmic granules of activated neutrophils results in increased local concentrations of LL-37 and cathelin. LL-37 (and possibly cathelin) contributes to killing of invading pathogens and promotes repair of damaged tissue by inducing re-epithelialization and angiogenesis.

damaged tissue by promoting reepithelialization of healing skin (Heilborn et al., 2003). This is suggested by high levels of LL-37 expression in human skin upon wounding (Dorschner et al., 2001; Heilborn et al., 2003), the ability of LL-37-specific antibodies to inhibit reepithelialization in a dose-dependent manner and by the decreased levels of LL-37 in chronic ulcers (Heilborn et al., 2003). LL-37 could contribute to cutaneous wound vascularization as well, since application of exogenous LL-37 results in angiogenesis both in the chorioallantoic membrane assay and in a rabbit hind-limb model of ischemia (Koczulla et al., 2003). The ability of this peptide to stimulate proliferation of cultured HUVECs and to cause endothelial sprouting from hamster aortic rings suggests that the angiogenic effect depends on direct activation of endothelial cells, a process that appears to be mediated by interaction of LL37 with FPRL1 expressed on endothelial cells (Koczulla et al., 2003).

\section{Role in host defense}

Additional studies are required to understand how the multiple activities of LL-37 impact host processes. However, several different lines of evidence already converge to indicate a crucial role of this peptide in vivo (reviewed in Nizet and Gallo, 2003).

Increased production of LL-37 has been observed in skin and mucosal epithelia in response to local and systemic infections as well as in inflammatory disorders and other skin pathologies (Frohm et al., 1997; Dorschner et al., 2001; Conner et al., 2002; Schaller-Bals et al., 2002; Ong et al., 2002; Paulsen et al., 2003; Kim et al., 2003; Jung et al, 2003), providing circumstantial evidence for a role of LL-37 in such conditions. Particularly, LL-37 and hBD-2 are upregulated in psoriatic skin but not in atopic dermatitis, which may render an explanation for the fact that patients with atopic dermatitis, but not psoriasis, suffer from frequent skin infections (Ong et al., 2002). Similarly, decreased levels of hCAP18/LL-37 have been associated with decreased protection against infection. This is well illustrated by the correlation between LL37 deficiency in neutrophils from patients with Morbus
Kostmann, a severe congenital neutropenia, and frequent occurrence of infections and chronic periodontal disease in these patients (Putsep et al., 2002). The involvement of LL-37 in prevention of oral bacterial infections is further supported by the ability of this peptide to efficiently kill common periodontal pathogens (Tanaka et al., 2000; Isogai et al., 2003).

It is revealing that bacteria themselves can cause depletion of LL-37. Indeed, expression of hCAP18/LL-37 is downregulated in gut biopsies of patients with Shigella infections as well as in Shigella-infected monocyte and epithelial-derived cell lines (Islam et al., 2001), suggesting that this may be a virulence feature of bacteria to compromise the intestinal innate defenses.

Augmentation of LL-37 by exogenous administration is a useful experimental strategy to assess capability of LL-37 to protect from microbial infection, as demonstrated using a genetic approach based on adenoviral-mediated hCAP18 gene transfer into respiratory epithelia (Bals et al., 1999a,b). Overexpression of recombinant hCAP18 in cystic-fibrosis (CF) respiratory epithelial cells reverses the CF-specific bacterial killing defect (Bals et al., 1999a). Furthermore, transfer of the hCAP18 gene into mouse airways results in decreased bacterial load and decreased inflammatory response in $P$. aeruginosa-infected mice (Bals et al., 1999b). In addition, systemic overexpression of this gene protects mice from septic death (Bals et al., $1999 b)$, which may partly reflect the high LPS-neutralizing capacity of LL-37 (Larrick et al., 1995; Kirikae et al., 1998; Turner et al., 1998; Scott et al., 2002).

\section{Activities and role in host defense of non-human cathelicidins}

Emphasis has been given in this review to hCAP18/LL-37 with respect to its human host. This should not overshadow the substantial contribution of non-human cathelicidins to the appreciation of the function and biology of this protein family in mammals. Furthermore, the activities of cathelicidin peptides have stimulated intensive studies aimed to exploit their therapeutic potential for the benefit of humans. 
The last part of this review briefly summarizes the results of several key experiments that highlight the contribution of non-human cathelicidin peptides to in vivo host protection and describes potential effects of two such peptides on mammalian cells (see Gennaro and Zanetti, 2000 and Zanetti et al., 2002 for a comprehensive account of structural and activity studies of the cathelicidin peptides).

Role in host defense (CRAMP, protegrins, SMAP-29) Mice have a single cathelicidin denoted CRAMP that is encoded by the Cnlp gene. The absence of other cathelicidins with similar functions has facilitated studies aimed at verifying the contribution of the CRAMP peptide to host defense. Targeted gene disruption with generation of mice null for the Cnlp gene has been quite informative in this respect, leading to an understanding of the role of CRAMP in skin infection (Nizet et al., 2001). Homozygous loss of Cnlp results in much larger and persistent skin lesions following infection by Group $A$ Streptococcus (GAS) than in wild-type mice (Nizet et al., 2001). Moreover, mast cells derived from knockout mice show significantly lower amounts of endogenous CRAMP and decreased ability to kill GAS, as compared with wildtype mice (Di Nardo et al., 2003). The protective effect of CRAMP against GAS has further been confirmed by generating a CRAMP-resistant GAS mutant and showing that wild-type mice infected with CRAMP-resistant GAS exhibit larger lesions than those infected with the parent GAS strain (Nizet et al., 2001). A corresponding function of LL-37 in human skin protection is reasonably expected, since murine CRAMP and human LL-37, albeit different in sequence, have similar amphipathic $\alpha$-helical structures and antimicrobial activity spectra.

A different approach, based on application of a neutrophil elastase-specific inhibitor (NEI) to prevent the maturation of cathelicidin peptides in a porcine skin wound model (Cole et al., 2001), has convincingly delineated the contribution of protegrins in the antimicrobial defenses of pigs. Lack of mature protegrins under these conditions leads to inefficient clearance of bacteria from the wound, and addition of exogenous protegrin or excess elastase to NEl-inhibited wound fluid restores the antimicrobial activity of the fluid (Cole et al., 2001). The effectiveness of PG-1 in preventing bacterial colonization in porcine skin wounds is further indicated by the marked reduction in the colony forming units after exogenous application of PG-1 to porcine skin wounds infected with Pseudomonas aeruginosa (Ceccarelli et al., 2001).

Clear evidence for host defense capacity of SMAP29 has come from the demonstration that intratracheal administration of this ovine peptide in a lamb pneumonia model induced by Mannheimia haemolytica reduces the bacterial concentration in bronchoalveolar fluid and in consolidated pulmonary tissues, as well as the severity of the lesions in the lungs (Brogden et al., 2001).

The potent and broad spectrum antimicrobial activity of SMAP-29 and protegrins and their ability to protect from infection in vivo have prompted a conspicuous number of studies aimed to assess their potential clinical development as novel anti-infective agents (Zanetti et al., 2002).
Effects on host cells (PR-39, BMAP-28)

Both the porcine PR-39 and the bovine BMAP-28 have been characterized for biological activities on mammalian cells (Table 3 ). PR-39 is a peculiar peptide and may contribute to the innate defenses of pigs with multiple activities. It belongs to the structural class of peptides that display tandemly repeated proline motifs in their sequences and have a non-lytic mechanism of antimicrobial activity (Gennaro et al., 2002). No visible membrane damage is detected in killed bacteria following treatment with PR-39 (Shi et al., 1996a). Instead, PR-39 causes inhibition of bacterial protein and DNA synthesis (Boman et al., 1993). These events may be mediated by specific recognition of intracellular target(s), as indirectly suggested by the ability of a peptide corresponding to the N-terminal 1-15 sequence of PR-39 to rapidly enter mammalian cells without permeabilizing the plasma membrane and to bind cytosolic proteins containing Src homology 3 (SH3) domains (Chan and Gallo, 1998). Indeed, PR-39 shows a wide range of effects on mammalian cells, suggesting its participation in various biological processes. PR-39 is chemotactic for neutrophils at 0.5-2 $\mu \mathrm{M}$ (Huang et al., 1997), impairs the production of reactive oxygen species via inhibition of the phagocyte NADPH oxidase complex (Shi et al., 1996b) and inhibits LPS-induced apoptosis of macrophages (Ramanathan et al., 2003), suggesting that it may contribute to the regulation of inflammation. In addition, PR-39 acts as a signal to induce the synthesis of syndecan-1 and -4 in cultured mesenchymal cells (Gallo et al., 1994). Members of the syndecan family of cell surface heparan sulfate proteoglycans are involved in wound healing (Bernfield et al., 1992). In this respect, PR39 is thought to function as a signaling molecule in wound repair. Furthermore, this peptide has been described as a putative regulator of angiogenesis and as an inhibitor of the ubiquitin-proteasome pathway-mediated degradation of $\mathrm{I}_{\mathrm{KB} \alpha}$ (Li et al., 2000; Gao et al., 2000), thereby affecting the expression of genes controlled by NF- $\mathrm{KB}$, a transcription factor with pleiotropic functions in immunity.

Most of these effects may be connected with the ability of PR-39 to enter cells and to bind SH3 domaincontaining proteins. The biological relevance of these findings obviously relates to the pig and possibly to bovids, where structurally similar proline-rich peptides have been identified. The presence of related peptides in other mammals, including humans, has not been demonstrated. However, there could be a therapeutic interest in the multiple activities of PR-39 concerning, for example, the potential for treatment of diseases such as ischemia-reperfusion injury (Korthuis et al., 2000).

The bovine BMAP-28 is an $\alpha$-helical cathelicidin peptide of 27 residues with an amidated C-terminus. This peptide may contribute to host defense by direct antimicrobial effects and by modulating the inflammatory/ immune response. In addition to killing a wide range of bacteria and fungi in vitro at the low sub- micromolar range of peptide concentrations (Skerlavaj et al., 1996), BMAP28 is toxic to cultured blood cells, causing cell membrane permeabilization and apoptosis in a variable proportion of the cells, with higher toxicity to hematopoietic tumor cell lines than normal leukocytes and to activated than resting human lymphocytes (Risso et al., 1998). The 
apoptotic effect likely depends on peptide-mediated induction of the mitochondrial permeability transition pore (MPTP), as suggested by the ability of BMAP-28 to target mitochondrial membranes and to induce cyclosporineinhibited decreases in the inner mitochondrial membrane potential and release of cytochrome $c$ (Risso et al., 2002). Although the in vivo relevance of these effects has not been established, the high susceptibility of proliferating lymphocytes suggests that this peptide may be implicated in the resolution of inflammation and could contribute via this mechanism to prevent excessive tissue injury caused by release of enzymes and other toxic cellular components.

\section{Conclusions and future trends}

The cathelicidin family was identified over a decade ago based on the presence of a conserved cathelin domain in every family member. The importance of peptides belonging to this family has since gained increased recognition as their role, both as endogenous antibiotics and as effector molecules of the innate immune system, has been defined. In-depth studies of the human cathelicidin suggest wide expression of this gene in human tissues that are involved in early protection against infection, and a significant contribution of LL-37 to host defense is indicated by increased susceptibility to infection in disease-associated or experimentally-induced peptide deficiencies. The potency and effectiveness of both human LL-37 and non-human cathelicidin peptides is demonstrated by their capacity to protect from infection after exogenous administration or by overexpression in animal models. Furthermore, their ability to interact and synergize in vitro to enhance the antimicrobial effects in experiments reflecting in vivo conditions has given insight into the full potential of the complex mixture of substances found at infection sites, strongly suggesting that the combined effort of different peptides greatly increases the global antibiotic action. Finally, the capacity of LL-37 to modulate or elicit various responses connected with host defense, such as chemotaxis of inflammatory and immune cells, activation of early defense cells and promotion of wound healing, indicates a high level of integration of this effector molecule with other innate immune mechanisms.

Despite substantial progress in our knowledge of the function of the human cathelicidin, several important issues remain to be clarified. Our understanding of the multiple activities of LL-37 unrelated to direct microbial killing is still incomplete and further in vitro and in vivo studies are needed to determine how these effects globally impact host processes. It is important to dissect the mechanisms that control the tissue-specific expression of the hCAP18/LL-37 gene, also in view of developing novel therapeutic strategies intended to potentiate endogenous production of this molecule. It is evident that hCAP18 is released as a two-domain protein and is cleaved to give two distinct molecules, both of which have been detected in physiological settings. To fully understand the functional potential of the human cathelicidin gene, we need a precise understanding of the in vivo role of the cathelin domain, which is yet unclear.

Finally, a large body of data indicates that both the human and non-human cathelicidin peptides are a promising source of lead compounds for the development of a novel class of anti-infective drugs. The rapid emergence of bacterial strains that are multiply resistant to conventional antibiotics urges an intensification of preclinical and clinical studies of these peptides in order to address what appears to be a major current threat to human health.

\section{References}

Agerberth, B., Lee, J.Y., Bergman, T., Carlquist, M., Boman, H.G., Mutt, V., and Jornvall, H. (1991). Amino acid sequence of PR-39. Isolation from pig intestine of a new member of the family of proline-arginine-rich antibacterial peptides. Eur. J. Biochem. 202, 849-854.

Agerberth, B., Gunne, H., Oderberg, J., Kogner, P., Boman, H.G., and Gudmundsson, G.H. (1995). FALL39 , a putative human peptide antibiotic, is cysteine-free and expressed in bone marrow and testis. Proc. Natl. Acad. Sci. USA. 92, 195-199.

Agerberth, B., Charo, J., Werr, J., Olsson, B., Idali, F., Lindbom, L., Kiessling, R., Jornvall, H., Wigzell, H., and Gudmundsson, G.H. (2000). The human antimicrobial and chemotactic peptides LL-37 and alpha-defensins are expressed by specific lymphocyte and monocyte populations. Blood 96, 3086-3093.

Andersson, E., Sorensen, O. E., Frohm, B., Borregaard, N., Egesten, A., and Malm, J. (2002). Isolation of human cationic antimicrobial protein-18 from seminal plasma and its association with prostasomes. Hum. Reprod. 17, 2529-2534.

Bagella, L., Scocchi, M., and Zanetti, M. (1995). cDNA sequences of three sheep myeloid cathelicidins. FEBS Lett. 376, 225-228.

Bals, R., Wang, X., Zasloff, M., and Wilson, J.M. (1998). The peptide antibiotic LL-37/hCAP-18 is expressed in epithelia of the human lung where it has broad antimicrobial activity at the airway surface. Proc. Natl. Acad. Sci. USA. 95, 9541-9546.

Bals, R., Weiner, D.J., Meegalla, R.L., and Wilson, J.M. (1999a). Transfer of a cathelicidin peptide antibiotic gene restores bacterial killing in a cystic fibrosis xenograft model. J. Clin. Invest. 103, 1113-1117.

Bals, R., Weiner, D.J., Moscioni, A.D., Meegalla, R.L., and Wilson, J.M. (1999b). Augmentation of innate host defense by expression of a cathelicidin antimicrobial peptide. Infect. Immun. 67, 6084-6089.

Bals, R., Lang, C., Weiner, D.J., Vogelmeier, C., Welsch, U., and Wilson, J.M. (2001). Rhesus monkey (Macaca mulatta) mucosal antimicrobial peptides are close homologues of human molecules. Clin. Diagn. Lab. Immunol. 8, 370-375.

Basanez, G., Shinnar, A.E., and Zimmerberg, J. (2002). Interaction of hagfish cathelicidin antimicrobial peptides with model lipid membranes. FEBS Lett. 532, 115120.

Bernfield, M., Kokenyesi, R., Kato, M., Hinkes, M.T., Spring, J., Gallo, R.L., and Lose, E.J. (1992). Biology of the syndecans: a family of transmembrane heparan sulfate proteoglycans. Annu. Rev. Cell Biol. 8, 365393.

Blankenvoorde, M.F., van't Hof, W., Walgreen-Weterings, E., van Steenbergen, T.J., Brand, H.S., Veerman, 
E.C., and Nieuw Amerongen, A.V. (1998). Cystatin and cystatin-derived peptides have antibacterial activity against the pathogen Porphyromonas gingivalis. Biol. Chem. 379, 1371-1375.

Boman, H.G., Agerberth, B., and Boman, A. (1993). Mechanisms of action on Escherichia coli of cecropin P1 and PR-39, two antibacterial peptides from pig intestine. Infect. Immun. 61, 2978-2984.

Brogden, K.A., Kalfa, V.C., Ackermann, M.R., Palmquist, D.E., McCray, P.B. Jr, and Tack, B.F. The ovine cathelicidin SMAP29 kills ovine respiratory pathogens in vitro and in an ovine model of pulmonary infection. Antimicrob. Agents Chemother. 45, 331-334.

Castiglioni, B., Scocchi, M., Zanetti, M., and Ferretti, L. (1996). Six antimicrobial peptide genes of the cathelicidin family map to bovine chromosome $22 \mathrm{q} 24$ by fluorescence in situ hybridization. Cytogen. Cell. Genet. 75, 240-242.

Ceccarelli, A.V., Cole, A.M., Park, A.K., Tahk, S., Yoshioka, D., and Ganz, T. (2001). Therapeutic effect of a pigderived peptide antibiotic on porcine wound infections. Comp. Med. 51, 75-79.

Chan, Y.R., and Gallo, R.L. (1998). PR-39, a syndecaninducing antimicrobial peptide, binds and affects p130(Cas). J. Biol. Chem. 273, 28978-28985.

Cole, A.M., Shi, J., Ceccarelli, A., Kim, Y.H., Park, A., and Ganz, T. (2001). Inhibition of neutrophil elastase prevents cathelicidin activation and impairs clearance of bacteria from wounds. Blood 97, 297-304.

Com, E., Bourgeon, F., Evrard, B., Ganz, T., Colleu, D., Jegou, B., and Pineau, C. (2003). Expression of antimicrobial defensins in the male reproductive tract of rats, mice, and humans. Biol. Reprod. 68, 95-104.

Conner, K., Nern, K., Rudisill, J., O'Grady, T., and Gallo, R.L. (2002). The antimicrobial peptide LL-37 is expressed by keratinocytes in condyloma acuminatum and verruca vulgaris. J. Am. Acad. Dermatol. 47, 347350.

Cowland, J.B., Johnsen, A.H., and Borregaard, N. (1995). hCAP-18, a cathelin/pro-bactenecin-like protein of human neutrophil specific granules. FEBS Lett. 368, 173-176.

Del Sal, G., Storici, P., Schneider, C., Romeo, D., and Zanetti, M. (1992). cDNA cloning of the neutrophil bactericidal peptide indolicidin. Biochem. Biophys. Res. Commun. 187, 467-472.

De Yang, Chen, Q., Schmidt, A.P., Anderson, G.M., Wang, J.M., Wooters, J., Oppenheim, J.J., and Chertov, O. (2000). LL-37, the neutrophil granule- and epithelial cell-derived cathelicidin, utilizes formyl peptide receptorlike 1 (FPRL1) as a receptor to chemoattract human peripheral blood neutrophils, monocytes, and T cells. J. Exp. Med. 192, 1069-1074.

Di Nardo, A., Vitiello, A., and Gallo, R.L. (2003). Cutting edge: mast cell antimicrobial activity is mediated by expression of cathelicidin antimicrobial peptide. J. Immunol. 170, 2274-2278.

Dorschner, R.A., Pestonjamasp, V.K., Tamakuwala, S., Ohtake, T., Rudisill, J., Nizet, V., Agerberth, B., Gudmundsson, G.H., and Gallo, R.L. (2001). Cutaneous injury induces the release of cathelicidin anti-microbial peptides active against group A Streptococcus. J. Invest. Dermatol. 117, 91-97.

Dorschner, R.A., Lin, K.H., Murakami, M., and Gallo, R.L. (2003). Neonatal skin in mice and humans expresses increased levels of antimicrobial peptides: innate immunity during development of the adaptive response. Pediatr. Res. 53, 566-572.

Frohm, M., Gunne, H., Bergman, A.C., Agerberth, B., Bergman, T., Boman, A., Liden, S., Jornvall, H., and Boman, H.G. (1996). Biochemical and antibacterial analysis of human wound and blister fluid. Eur. J. Biochem. 237, 86-92.

Frohm, M., Agerberth, B., Ahangari, G., Stahle-Backdahl, M., Liden, S., Wigzell, H., and Gudmundsson, G.H. (1997). The expression of the gene coding for the antibacterial peptide LL-37 is induced in human keratinocytes during inflammatory disorders. J. Biol. Chem. 272, 15258-15263.

Frohm Nilsson, M., Sandstedt, B., Sorensen, O., Weber, G., Borregaard, N., and Stahle-Backdahl, M. (1999). The human cationic antimicrobial protein (hCAP-18), a peptide antibiotic, is widely expressed in human squamous epithelia and colocalizes with interleukin-6. Infect. Immun. 67, 2561-2566.

Gallo, R.L., Ono, M., Povsic, T., Page, C., Eriksson, E., Klagsbrun, M., and Bernfield, M. (1994). Syndecans, cell surface heparan sulfate proteoglycans, are induced by a proline-rich antimicrobial peptide from wounds. Proc. Natl. Acad. Sci. USA. 91, 11035-11039.

Gallo, R.L., Kim, K.J., Bernfield, M., Kozak, C.A., Zanetti, M., Merluzzi, L., and Gennaro, R. (1997). Identification of CRAMP, a cathelin related antimicrobial peptide expressed in the embryonic and adult mouse. J. Biol. Chem. 272, 13088-13093.

Gao, Y., Lecker, S., Post, M.J., Hietaranta, A.J., Li, J., Volk, R., Li, M., Sato, K., Saluja, A. K., Steer, M.L., Goldberg, A.L., and Simons, M. (2000). Inhibition of ubiquitin-proteasome pathway-mediated I kappa B alpha degradation by a naturally occurring antibacterial peptide. J. Clin. Invest. 106, 439-448.

Gennaro R., Skerlavaj B., and Romeo D. (1989). Purification, composition, and activity of two bactenecins, antibacterial peptides of bovine neutrophils. Infect Immun. 57, 3142-3146.

Gennaro, R., and Zanetti, M. (2000). Structural features and biological activities of the cathelicidin-derived antimicrobial peptides. Biopolymers 55, 31-49.

Gennaro, R., Zanetti, M., Benincasa, M., Podda, E., and Miani, M. (2002). Pro-rich antimicrobial peptides from animals: structure, biological functions and mechanism of action. Curr. Pharm. Des. 8, 763-778.

Giacometti, A., Cirioni, O., Del Prete, M.S., Skerlavaj, B., Circo, R., Zanetti, M., and Scalise, G. (2003a). In vitro effect on Cryptosporidium parvum of shortterm exposure to cathelicidin peptides. J. Antimicrob. Chemother. 51, 843-847.

Giacometti, A., Cirioni, O., Ghiselli, R., Mocchegiani, F., D'Amato, G., Circo, R., Orlando, F., Skerlavaj, B., Silvestri, C., Saba, V., Zanetti, M., and Scalise, G. (2003b). Cathelicidin peptide SMAP-29 Prevents Endotoxin-Induced Mortality in Rat Models of Septic 
Shock. Am. J. Respir. Crit. Care. Med. (Epub ahead of print).

Gudmundsson, G.H., Magnusson, K.P., Chowdhary, B.P., Johansson, M., Andersson, L., and Boman, H.G. (1995). Structure of the gene for porcine peptide antibiotic PR-39, a cathelin gene family member: comparative mapping of the locus for the human peptide antibiotic FALL-39. Proc. Natl. Acad. Sci. USA. 92, 7085-7089.

Gudmundsson, G.H., Agerberth, B., Odeberg, J., Bergman, T., Olsson, B., and Salcedo, R. (1996). The human gene FALL39 and processing of the cathelin precursor to the antibacterial peptide LL-37 in granulocytes. Eur. J. Biochem. 238, 325-332.

Hamil, K.G., Liu, Q., Sivashanmugam, P., Yenugu, S., Soundararajan, R., Grossman, G., Richardson, R.T., Zhang, Y.L., O'Rand, M.G., Petrusz, P., French, F.S., and Hall, S.H. (2002). Cystatin 11: a new member of the cystatin type 2 family. Endocrinology 143, 2787-2796.

Hammami-Hamza, S., Doussau, M., Bernard, J., Rogier, E., Duquenne, C., Richard, Y., Lefevre, A., and Finaz, C. (2001). Cloning and sequencing of SOB3, a human gene coding for a sperm protein homologous to an antimicrobial protein and potentially involved in zona pellucida binding. Mol. Hum. Reprod. 7, 625-632.

Hase, K., Eckmann, L., Leopard, J.D., Varki, N., and Kagnoff, M.F. (2002). Cell differentiation is a key determinant of cathelicidin LL-37/human cationic antimicrobial protein 18 expression by human colon epithelium. Infect. Immun. 70, 953-963.

Heilborn, J.D., Nilsson, M.F., Kratz, G., Weber, G., Sorensen, O., Borregaard, N., and Stahle-Backdahl, M. (2003). The cathelicidin anti-microbial peptide LL-37 is involved in re-epithelialization of human skin wounds and is lacking in chronic ulcer epithelium. J. Invest. Dermatol. 120, 379-389.

Henzler Wildman, K.A., Lee, D.K., and Ramamoorthy, A. (2003). Mechanism of lipid bilayer disruption by the human antimicrobial peptide, LL-37. Biochemistry 42, 6545-6558.

Hirata, M., Shimomura, Y., Yoshida, M., Morgan, J.G., Palings, I., Wilson, D., Yen, M.H., Wright, S.C., and Larrick, J.W. (1994). Characterization of a rabbit cationic protein (CAP18) with lipopolysaccharide-inhibitory activity. Infect. Immun. 62, 1421-1426.

Huang, H.J., Ross, C.R., and Blecha, F. (1997). Chemoattractant properties of PR-39, a neutrophil antibacterial peptide. J. Leukoc. Biol. 61, 624-629.

Huttner, K.M., Lambeth, M.R., Burkin, H.R., Burkin, D.J., and Broad, T.E. (1998). Localization and genomic organization of sheep antimicrobial peptide genes. Gene 206, 85-91.

Islam, D., Bandholtz, L., Nilsson, J., Wigzell, H., Christensson, B., Agerberth, B., and Gudmundsson, G. (2001). Downregulation of bactericidal peptides in enteric infections: a novel immune escape mechanism with bacterial DNA as a potential regulator. Nat. Med. 7, 180-185.

Isogai, E., Isogai, H., Matuo, K., Hirose, K., Kowashi, Y., Okumuara, K., and Hirata, M. (2003) Sensitivity of genera Porphyromonas and Prevotella to the bactericidal action of C-terminal domain of human
CAP18 and its analogues. Oral Microbiol. Immunol. 18, 329-332.

Johansson, J., Gudmundsson, G.H., Rottenberg, M.E., Berndt, K.D., and Agerberth, B. (1998). Conformationdependent antibacterial activity of the naturally occurring human peptide LL-37. J. Biol. Chem. 273, 3718-3724.

Jung, H.H., Chae, S.W., Jung, S.K., Kim, S.T., Lee, H.M. and Hwang, S.J. (2003). Expression of a cathelicidin antimicrobial peptide is augmented in cholesteatoma. Laryngoscope 113, 432-435.

Kim, S.T., Cha, H.E., Kim, D.Y., Han, G.C., Chung, Y.S., Lee, Y.J., Hwang, Y.J., and Lee, H.M.. (2003). Antimicrobial peptide LL-37 is upregulated in chronic nasal inflammatory disease. Acta Otolaryngol. 23, 8185.

Kirikae, T., Hirata, M., Yamasu, H., Kirikae, F., Tamura, H., Kayama, F., Nakatsuka, K., Yokochi, T., and Nakano, M. (1998). Protective effects of a human 18-kilodalton cationic antimicrobial protein (CAP18)-derived peptide against murine endotoxemia. Infect. Immun. 66, 18611868.

Koczulla, R., Von Degenfeld, G., Kupatt, C., Krotz, F., Zahler, S., Gloe, T., Issbrucker, K., Unterberger, P., Zaiou, M., Lebherz, C., Karl, A., Raake, P., Pfosser, A., Boekstegers, P., Welsch, U., Hiemstra, P.S., Vogelmeier, C., Gallo, R.L., Clauss, M., and Bals, R. (2003). An angiogenic role for the human peptide antibiotic LL-37/ hCAP-18. J. Clin. Invest. 111, 1665-1672.

Kokryakov, V.N., Harwig, S.S.L., Panyutich, E.A., Shevchenko, A.A., Aleshina, G.M., Shamova, O.V., Korneva, H.A., and Lehrer, R.I. (1993). Protegrins: leukocyte antimicrobial peptides that combine features of corticostatic defensins and tachyplesins. FEBS Lett. 327, 231-236.

Kopitar, M., Ritonja, A., Popovic, T., Gabrijelcic, D., Krizaj, I., and Turk, V. (1989). A new type of low-molecular mass cysteine proteinase inhibitor from pig leukocytes. Biol. Chem. Hoppe. Seyler. 370, 1145-1151.

Korthuis, R.J., Gute, D.C., Blecha, F., and Ross, C.R. (2000). PR-39, a proline/arginine-rich antimicrobial peptide, prevents postischemic microvascular dysfunction. Am. J. Physiol. Heart Circ. Physiol. 277, H1007-H1013.

Larrick, J.W., Morgan, J.G., Palings, I., Hirata, M., and Yen, M.H. (1991). Complementary DNA sequence of rabbit CAP18a unique lipopolysaccharide binding protein. Biochem. Biophys. Res. Commun. 179, 170-175.

Larrick, J.W., Hirata, M., Zheng, H., Zhong, J., Bolin, D., Cavaillon, J.M., Warren, H.S., and Wright, S.C. (1994). A novel granulocyte-derived peptide with lipopolysaccharide-neutralizing activity. J. Immunol. 152, 231-240.

Larrick, J.W., Hirata, M., Balint, R.F., Lee, J., Zhong, J., and Wright, S.C. (1995). Human CAP18: a novel antimicrobial lipopolysaccharide-binding protein. Infect. Immun. 63, 1291-1297.

Larrick, J.W., Lee, J., Ma, S., Li, X., Francke, U., Wright, S.C., and Balint, R.F. (1996). Structural, functional analysis and localization of the human CAP18 gene. FEBS Lett. 398, 74-80.

Levy, O., Weiss, J., Zarember, K., Ooi, C.E., and Elsbach, P. (1993). Antibacterial 15-kDa protein isoforms (p15s) 
are members of a novel family of leukocyte proteins. J. Biol. Chem. 268, 6058-60.

Li, J., Post, M., Volk, R., Gao, Y., Li, M., Metais, C., Sato, K., Tsai, J., Aird, W., Rosenberg, R., Hampton, T.G., Li, J., Sellke, F., Carmeliet, P., and Simons, M. (2000). PR39 , a peptide regulator of angiogenesis. Nat. Med. 6 , 49-55.

Lynn, D.J., Higgs, R., Gaines, S., Tierney, J., James, T., Lloyd, A.T., Fares, M.A., Mulcahy, G. and O'Farrelly, C. (2004). Bioinformatic discovery and initial characterisation of nine novel antimicrobial peptide genes in the chicken. Immunogenetics 56, 170-177.

Lysenko, E.S., Gould, J., Bals, R., Wilson, J.M., and Weiser, J.N. (2000). Bacterial phosphorylcholine decreases susceptibility to the antimicrobial peptide LL-37/hCAP18 expressed in the upper respiratory tract. Infect. Immun. 68, 1664-1671.

Liu, A.Y., Destoumieux, D., Wong, A.V., Park, C.H., Valore, E.V., Liu, L., and Ganz, T. (2002). Human betadefensin-2 production in keratinocytes is regulated by interleukin-1, bacteria, and the state of differentiation. J. Invest. Dermatol. 118, 275-281.

Liu, L., Roberts, A.A., and Ganz, T. (2003). By IL1 signaling, monocyte-derived cells dramatically enhance the epidermal antimicrobial response to lipopolysaccharide. J. Immunol. 170, 575-580.

Mahoney, M.M., Lee, A.Y., Brezinski-Caliguri, D.J., and Huttner, K.M. (1995). Molecular analysis of the sheep cathelin family reveals a novel antimicrobial peptide. FEBS Lett. 377, 519-522.

Malm, J., Sorensen, O., Persson, T., Frohm-Nilsson, M., Johansson, B., Bjartell, A., Lilja, H., Stahle-Backdahl, M., Borregaard, N., and Egesten, A. (2000). The human cationic antimicrobial protein (hCAP-18) is expressed in the epithelium of human epididymis, is present in seminal plasma at high concentrations, and is attached to spermatozoa. Infect. Immun. 68, 4297-4302.

Marchini, G., Lindow, S., Brismar, H., Stabi, B., Berggren, V., Ulfgren, A.K., Lonne-Rahm, S., Agerberth, B., and Gudmundsson, G.H. (2002). The newborn infant is protected by an innate antimicrobial barrier: peptide antibiotics are present in the skin and vernix caseosa. Br. J. Dermatol. 147, 1127-1134.

McGwire, B.S., Olson, C.L., Tack, B.F., and Engman, D.M. (2003). Killing of African trypanosomes by antimicrobial peptides. J. Infect. Dis. 188, 146-152.

Midorikawa, K., Ouhara, K., Komatsuzawa, H., Kawai, T., Yamada, S., Fujiwara, T., Yamazaki, K., Sayama, K., Taubman, M.A., Kurihara, H., Hashimoto, K., and Sugai, M. (2003). Staphylococcus aureus susceptibility to innate antimicrobial peptides, beta-defensins and CAP18, expressed by human keratinocytes. Infect. Immun. 71, 3730-3739.

Moscinski, L.C., and Hill, B. (1995). Molecular cloning of a novel myeloid granule protein. J. Cell Biochem. 59, 431-442.

Murakami, M., Ohtake, T., Dorschner, R.A., Schittek, B., Garbe, C., and Gallo, R.L. (2002a). Cathelicidin anti-microbial peptide expression in sweat, an innate defense system for the skin. J. Invest. Dermatol. 119, 1090-1095.
Murakami, M., Ohtake, T., Dorschner, R.A., and Gallo, R.L. (2002b). Cathelicidin antimicrobial peptides are expressed in salivary glands and saliva. J. Dent. Res. 81, 845-850.

Nagaoka, I., Tsutsumi-Ishii, Y., Yomogida, S., and Yamashita, T.J. (1997). Isolation of cDNA encoding guinea pig neutrophil cationic antibacterial polypeptide of $11 \mathrm{kDa}$ (CAP11) and evaluation of CAP11 mRNA expression during neutrophil maturation. Biol. Chem. 272, 22742-22750.

Nagaoka, I., Hirota, S., Yomogida, S., Ohwada, A., and Hirata, M. (2000). Synergistic actions of antibacterial neutrophil defensins and cathelicidins. Inflamm. Res. 49, 73-79.

Niyonsaba, F., Hirata, M., Ogawa, H., and Nagaoka, I. (2003). Epithelial cell-derived antibacterial peptides human beta-defensins and cathelicidin: multifunctional activities on mast cells. Curr. Drug Targets Inflamm. Allergy 2, 224-231.

Nizet, V., Ohtake, T., Lauth, X., Trowbridge, J., Rudisill, J., Dorschner, R.A., Pestonjamasp, V., Piraino, J., Huttner, K., and Gallo, R.L. (2001). Innate antimicrobial peptide protects the skin from invasive bacterial infection. Nature 414, 454-457.

Nizet, V., and Gallo, R.L. (2003). Cathelicidins and innate defense against invasive bacterial infection. Scand. J. Infect. Dis. 35, 670-676.

Nomura, I., Goleva, E., Howell, M.D., Hamid, Q.A., Ong, P.Y., Hall, C.F., Darst, M.A., Gao, B., Boguniewicz, M., Travers, J.B., and Leung, D.Y. (2003). Cytokine milieu of atopic dermatitis, as compared to psoriasis, skin prevents induction of innate immune response genes. J. Immunol. 171, 3262-3269.

Ohgami, K., Ilieva, I.B., Shiratori, K., Isogai; E., Yoshida, K., Kotake, S., Nishida, T., Mizuki, N., and Ohno, S. (2003). Effect of human cationic antimicrobial protein 18 Peptide on endotoxin-induced uveitis in rats. Invest. Ophthalmol. Vis. Sci. 44, 4412-4418.

Ong, P.Y., Ohtake, T., Brandt, C., Strickland, I., Boguniewicz, M., Ganz, T., Gallo, R.L., and Leung, D.Y. (2002). Endogenous antimicrobial peptides and skin infections in atopic dermatitis. N. Engl. J. Med. 347, 1151-1160.

Oren, Z., Lerman, J.C., Gudmundsson, G.H., Agerberth, B., and Shai, Y. (1999). Structure and organization of the human antimicrobial peptide LL-37 in phospholipid membranes: relevance to the molecular basis for its non-cell-selective activity. Biochem. J. 341, 501-513.

Panyutich, A., Shi, J., Boutz, P.L., Zhao, C., and Ganz, T. (1997). Porcine polymorphonuclear leukocytes generate extracellular microbicidal activity by elastasemediated activation of secreted proprotegrins. Infect. Immun. 65, 978-985.

Paulsen, F., Pufe, T., Conradi, L., Varoga, D., Tsokos, M., Papendieck, J., and Petersen, W. (2003). Antimicrobial peptides are expressed and produced in healthy and inflamed human synovial membranes. J. Pathol. 198, 369-377.

Popsueva, A.E., Zinovjeva, M.V., Visser, J.W.M., Zijlmans, J.M., Fibbe, W.E., and Belyavsky, A.V. (1996). A novel murine cathelin-like protein expressed in bone marrow. FEBS Lett. 391, 5-8. 
Putsep, K., Carlsson, G., Boman, H.G., and Andersson, M. (2002). Deficiency of antibacterial peptides in patients with morbus Kostmann: an observation study. Lancet 360, 1144-1149.

Ramanathan, B., Wu, H., Ross, C.R., and Blecha, F. (2003). PR-39, a porcine antimicrobial peptide, inhibits apoptosis: involvement of caspase-3. Dev. Comp. Immunol. 28, 163-169.

Risso, A., Zanetti, M., and Gennaro, R. (1998). Cytotoxicity and apoptosis mediated by two peptides of innate immunity. Cell. Immunol. 189, 107-115.

Risso, A., Braidot, E., Sordano, M.C., Vinello, A., Macrì, F., Skerlavaj, B., Zanetti, M., Gennaro, R., and Bernardi, P. (2002). BMAP-28, an antibiotic peptide of innate immunity, induces cell death through opening of the mitochondrial permeability transition pore. Mol. Cell. Biol. 22, 1926-1935.

Ritonja, A., Kopitar, M., Jerala, R., and Turk, V. (1989). Primary structure of a new cysteine proteinase inhibitor from pig leucocytes. FEBS Lett. 255, 211-214.

Romeo, D., Skerlavaj, B., Bolognesi, M., and Gennaro, R. (1988). Structure and bactericidal activity of an antibiotic dodecapeptide purified from bovine neutrophils. J. Biol. Chem. 263, 9573-9575.

Saiman, L., Tabibi, S., Starner, T.D., San Gabriel, P., Winokur, P.L., Jia, H.P., McCray, P.B. Jr, and Tack, B.F. (2001). Cathelicidin peptides inhibit multiply antibioticresistant pathogens from patients with cystic fibrosis. Antimicrob. Agents Chemother. 45, 2838-2844.

Sanchez, J.F., Hoh, F., Strub, M.P., Aumelas, A., and Dumas, C. (2002). Structure of the cathelicidin motif of protegrin-3 precursor: structural insights into the activation mechanism of an antimicrobial protein. Structure (Camb) 10, 1363-1370.

Schaller-Bals, S., Schulze, A., and Bals, R. (2002). Increased levels of antimicrobial peptides in tracheal aspirates of newborn infants during infection. Am. J. Respir. Crit. Care Med. 165, 992-995.

Schauber, J., Svanholm, C., Termen, S., Iffland, K., Menzel, T., Scheppach, W., Melcher, R., Agerberth, B., Luhrs, H., and Gudmundsson, G.H. (2003). Expression of the cathelicidin LL-37 is modulated by short chain fatty acids in colonocytes: relevance of signalling pathways. Gut 52, 735-741.

Scheetz, T., Bartlett, J.A., Walters, J.D., Schutte, B.C., Casavant, T.L., and McCray, P.B. Jr. (2002). Genomicsbased approaches to gene discovery in innate immunity. Immunol. Rev. 190, 137-145.

Schmidtchen, A., Frick, I.M., Andersson, E., Tapper, H., and Bjorck, L. (2002). Proteinases of common pathogenic bacteria degrade and inactivate the antibacterial peptide LL-37. Mol. Microbiol. 46, 157-168.

Scocchi, M., Skerlavaj, B., Romeo, D., and Gennaro, R. (1992). Proteolytic cleavage by neutrophil elastase converts inactive storage proforms to antibacterial bactenecins. Eur. J. Biochem. 209, 589-595.

Scocchi, M., Romeo, D., and Zanetti, M. (1994). Molecular cloning of Bac7, a proline- and arginine- rich antimicrobial peptide from bovine neutrophils. FEBS Lett. 352, 197-200.

Scocchi, M., Wang, S., and Zanetti, M. (1997). Structural organization of the bovine cathelicidin gene family and identification of a novel member. FEBS Lett. 417, 311315.

Scocchi, M., Bontempo, D., Boscolo, S., Tomasinsig, L., Giulotto, E., and Zanetti, M. (1999). Novel cathelicidins in horse leukocytes. FEBS Lett. 57, 459-464.

Scott, M.G., Davidson, D.J., Gold, M.R., Bowdish, D., and Hancock, R.E. (2002). The human antimicrobial peptide LL-37 is a multifunctional modulator of innate immune responses. J. Immunol. 169, 3883-3891.

Selsted, M.E., Novotny, M.J., Morris, W.L., Tang, Y.-Q., Smith, W., and Cullor, J.S. (1992). Indolicidin, a novel bactericidal tridecapeptide amide from neutrophils. J. Biol. Chem. 267, 4292-4295.

Shamova, O., Brogden, K.A., Zhao, C., Nguyen, T., Kokryakov, V.N., and Lehrer, R.I. (1999). Purification and properties of proline-rich antimicrobial peptides from sheep and goat leukocytes. Infect. Immun. 67, 4106-4111.

Shi, J., Ross, C.R., Chengappa, M.M., Sylte, M.J., McVey, D.S., and Blecha, F. (1996a). Antibacterial activity of a synthetic peptide (PR-26) derived from PR-39, a proline-arginine-rich neutrophil antimicrobial peptide. Antimicrob. Agents Chemother. 40, 115-121.

Shi, J., Ross, C.R., Leto, T.L., and Blecha, F. (1996b). PR-39, a proline-rich antibacterial peptide that inhibits phagocyte NADPH oxidase activity by binding to Src homology 3 domains of p47 phox. Proc. Natl. Acad. Sci. USA. 93, 6014-6018.

Shoemaker, K., Holloway, J.L., Whitmore, T.E., Maurer, M., and Feldhaus, A.L. (2000). Molecular cloning, chromosome mapping and characterization of a testisspecific cystatin-like cDNA, cystatin T. Gene. 245, 103108.

Skerlavaj, B., Gennaro, R., Bagella, L., Merluzzi, L., Risso, A., and Zanetti, M. (1996). Biological characterization of two novel cathelicidin-derived peptides and identification of structural requirements for their antimicrobial and cell lytic activities. J. Biol. Chem. 271, 28375-28381.

Smeianov, V., Scott, K., and Reid, G. (2000). Activity of cecropin P1 and FA-LL-37 against urogenital microflora. Microbes Infect. 2, 773-777.

Sorensen, O., Cowland, J.B., Askaa, J., and Borregaard, N. (1997a). An ELISA for hCAP-18, the cathelicidin present in human neutrophils and plasma. J. Immunol. Methods. 206, 53-59.

Sorensen, O., Arnljots, K., Cowland, J.B., Bainton, D.F., and Borregaard, N. (1997b). The human antibacterial cathelicidin, hCAP-18, is synthesized in myelocytes and metamyelocytes and localized to specific granules in neutrophils. Blood 90, 2796-2803.

Sorensen, O., Bratt, T., Johnsen, A.H., Madsen, M.T., and Borregaard, N. (1999). The human antibacterial cathelicidin, hCAP-18, is bound to lipoproteins in plasma. J. Biol. Chem. 274, 22445-22451.

Sorensen, O.E., Follin, P., Johnsen, A.H., Calafat, J., Tjabringa, G.S., Hiemstra, P.S., and Borregaard, N. (2001). Human cathelicidin, hCAP-18, is processed to the antimicrobial peptide LL-37 by extracellular cleavage with proteinase 3. Blood 97, 3951-3959.

Sorensen, O.E., Cowland, J.B., Theilgaard-Monch, K., Liu, L., Ganz, T., and Borregaard, N. (2003a). Wound healing and expression of antimicrobial peptides/ 
polypeptides in human keratinocytes, a consequence of common growth factors. J. Immunol. 170, 5583-5589.

Sorensen, O.E., Gram, L., Johnsen, A.H., Andersson, E., Bangsboll, S., Tjabringa, G.S., Hiemstra, P.S., Malm, J., Egesten, A., and Borregaard, N. (2003b). Processing of seminal plasma hCAP-18 to ALL-38 by gastricsin: a novel mechanism of generating antimicrobial peptides in vagina. J. Biol. Chem. 278, 28540-28546.

Storici, P., Del Sal, G., Schneider, C., and Zanetti, M. (1992). cDNA sequence analysis of an antibiotic dodecapeptide from neutrophils. FEBS Lett. 314, 187190.

Storici, P., and Zanetti, M. (1993a). A cDNA derived from pig bone marrow cells predicts a sequence identical to the intestinal antibacterial peptide PR-39. Biochem. Biophys. Res. Commun. 196, 1058-1065.

Storici, P., and Zanetti, M. (1993b). A novel cDNA sequence encoding a pig leukocyte antimicrobial peptide with a cathelin-like pro-sequence. Biochem. Biophys. Res. Commun. 196, 1363-1368.

Storici, P., Scocchi, M., Tossi, A., Gennaro, R., and Zanetti, M. (1994). Chemical synthesis and biological activity of a novel antibacterial peptide deduced from a pig myeloid cDNA. FEBS Lett. 337, 303-307.

Storici, P., Tossi, A., Lenarcic, B., and Romeo, D. (1996). Purification and structural characterization of bovine cathelicidins, precursors of antimicrobial peptides. Eur. J. Biochem. 238, 769-776.

Strukelj, B., Pungercar, J., Kopitar, G., Renko, M., Lenarcic, B., Berbic, S., and Turk, V. (1995). Molecular cloning and identification of a novel porcine cathelinlike antibacterial peptide precursor. Biol. Chem. Hoppe Seyler 376, 507-510.

Taggart, C.C., Greene, C.M., Smith, S.G., Levine, R.L., McCray, P.B. Jr, O'Neill, S., and McElvaney, N.G. (2003). Inactivation of human beta-defensins 2 and 3 by elastolytic cathepsins. J. Immunol. 171, 931-937.

Tanaka, D., Miyasaki, K.T., and Lehrer, R.I. (2000). Sensitivity of Actinobacillus actinomycetemcomitans and Capnocytophaga spp. to the bactericidal action of LL-37: a cathelicidin found in human leukocytes and epithelium. Oral Microbiol. Immunol. 15, 226-231.

Termen, S., Tollin, M., Olsson, B., Svenberg, T., Agerberth, B., and Gudmundsson, G. H. (2003). Phylogeny, processing and expression of the rat cathelicidin rCRAMP: a model for innate antimicrobial peptides. Cell. Mol. Life 60, 536-549.

Tjabringa, G.S., Aarbiou, J., Ninaber, D.K., Drijfhout, J.W., Sorensen, O.E., Borregaard, N., Rabe, K.F., and Hiemstra, P.S. (2003). The Antimicrobial Peptide LL37 Activates Innate Immunity at the Airway Epithelial Surface by Transactivation of the Epidermal Growth Factor Receptor. J. Immunol. 171, 6690-6666.

Tomasinsig, L., Scocchi, M., Di Loreto, C., Artico, D., and Zanetti, M. (2002). Inducible expression of an antimicrobial peptide of the innate immunity in polymorphonuclear leukocytes. J. Leukoc. Biol. 72, 1003-1010.

Tossi, A., Scocchi, M., Zanetti, M., Storici, P., and Gennaro, R. (1995). PMAP-37, a novel pig myeloid antibacterial peptide. Eur. J. Biochem. 228, 941-946.
Tossi, A., Sandri, L., and Giangaspero, A. (2000). Amphipathic, alpha-helical antimicrobial peptides. Biopolymers 55, 4-30.

Tsutsumi-Ishii, Y., and Nagaoka I. (2003). Modulation of human beta-defensin-2 transcription in pulmonary epithelial cells by lipopolysaccharide-stimulated mononuclear phagocytes via proinflammatory cytokine production. J. Immunol. 170, 4226-4236.

Turner, J., Cho, Y., Dinh, N.N., Waring, A.J., and Lehrer, R.I. (1998). Activities of LL-37, a cathelin-associated antimicrobial peptide of human neutrophils. Antimicrob. Agents Chemother. 42, 2206-2214.

Uzzell, T., Stolzenberg, E.D., Shinnar, A.E., and Zasloff, M. (2003). Hagfish intestinal antimicrobial peptides are ancient cathelicidins. Peptides 24, 1655-1667.

Verbanac, D., Zanetti, M., and Romeo, D. (1993). Chemotactic and protease-inhibiting activities of antibiotic peptide precursors. FEBS Lett. 317, 255258.

Wang, Y., Agerberth, B., Lothgren, A., Almstedt, A., and Johansson, J. (1998). Apolipoprotein A-I binds and inhibits the human antibacterial/cytotoxic peptide LL37. J. Biol. Chem. 273, 33115-33118.

Warren, H.S., Matyal, R., Allaire, J.E., Yarmush, D., Loiselle, P., Hellman, J., Paton, B.G., and Fink, M.P. (2003). Protective efficacy of CAP18106-138immunoglobulin $\mathrm{G}$ in sepsis. J. Infect. Dis. 188, 13821393.

Wiese, A., Gutsmann, T., and Seydel, U. (2003). Towards antibacterial strategies: studies on the mechanisms of interaction between antibacterial peptides and model membranes. J. Endotoxin Res. 9, 67-84.

Wright, W.W., Smith, L., Kerr, C., and Charron, M. (2003). Mice that express enzymatically inactive cathepsin L exhibit abnormal spermatogenesis. Biol. Reprod. 68, 680-687.

Wu, H., Zhang, G., Ross, C.R., and Blecha, F. (1999). Cathelicidin gene expression in porcine tissues: roles in ontogeny and tissue specificity. Infect. Immun. 67, 439-442.

Wu, H., Zhang, G., Minton, J.E., Ross, C.R., and Blecha, F. (2000). Regulation of cathelicidin gene expression: induction by lipopolysaccharide, interleukin-6, retinoic acid, and Salmonella enterica serovar typhimurium infection. Infect. Immun. 68, 5552-5558.

Yan, H., and Hancock, R.E. (2001). Synergistic interactions between mammalian antimicrobal peptides. Antimicrob. Agents Chemother. 45, 1558-1560.

Yang, Y., Sanchez, J.F., Strub, M.P., Brutscher, B., and Aumelas, A. (2003). NMR structure of the cathelin-like domain of the protegrin-3 precursor. Biochemistry 42, 4669-80.

Yang, Y.H., Zheng, G.G., Li, G., Zhang, B., Song, Y.H., and Wu, K.F. (2003). Expression of LL-37/hCAP-18 gene in human leukemia cells. Leuk. Res. 27, 947-950.

Yenugu, S., Hamil, K.G., Birse, C.E., Ruben, S.M., French, F.S., and Hall, S.H. (2003). Antibacterial properties of the sperm-binding proteins and peptides of human epididymis 2 (HE2) family; salt sensitivity, structural dependence and their interaction with outer and cytoplasmic membranes of Escherichia coli. Biochem. J. 372, 473-483. 
Yount, N.Y., Yuan, J., Tarver, A., Castro, T., Diamond G., Tran, P.A., Levy, J.N., McCullough, C., Cullor, J.S., Bevins, C.L., and Selsted, M.E. (1999). Cloning and expression of bovine neutrophil beta-defensins. Biosynthetic profile during neutrophilic maturation and localization of mature peptide to novel cytoplasmic dense granules. J. Biol. Chem. 274, 26249-26258.

Zaiou, M., Nizet, V., and Gallo, R.L. (2003). Antimicrobial and protease inhibitory functions of the human cathelicidin (hCAP18/LL-37) prosequence. J. Invest. Dermatol. 120, 810-816.

Zanetti, M., Litteri, L., Gennaro, R., Horstmann, H., and Romeo, D. (1990). Bactenecins, defense polypeptides of bovine neutrophils, are generated from precursor molecules stored in the large granules. J. Cell Biol. 111, 1363-1371.

Zanetti, M., Litteri, L., Griffiths, G., Gennaro, R., and Romeo, D. (1991). Stimulus-induced maturation of probactenecins, precursors of neutrophil antimicrobial polypeptides. J. Immunol. 146, 4295-4300.

Zanetti, M., Del Sal, G., Storici, P., Schneider, C., and Romeo, D. (1993). The cDNA sequence of the neutrophil antibiotic Bac5 predicts a pro-sequence homologous to a cysteine proteinase inhibitor, that is common to other neutrophil antibiotics. J. Biol. Chem. 268, 522-526.

Zanetti, M., Storici, P., Tossi, A., Scocchi, M., and Gennaro, R. (1994). Molecular cloning and chemical synthesis of a novel antibacterial peptide derived from pig myeloid cells. J. Biol. Chem. 269, 7855-7858.
Zanetti, M., Gennaro, R., and Romeo, D. (1995). Cathelicidins: a novel protein family with a common proregion and a variable C-terminal antimicrobial domain. FEBS Lett. 374, 1-5.

Zanetti, M., Gennaro, R., Scocchi, M., and Skerlavaj B. (2000). Structure and biology of cathelicidins. Adv. Exp. Med. Biol. 479, 203-218.

Zanetti, M., Gennaro, R., Skerlavaj, B., Tomasinsig, L., and Circo, R. (2002). Cathelicidin peptides as candidates for a novel class of antimicrobials. Curr. Pharm. Des. 8, 779-793.

Zarember, K.A., Katz, S.S., Tack, B.F., Doukhan, L., Weiss, J., and Elsbach, P. (2002). Host defense functions of proteolytically processed and parent (unprocessed) cathelicidins of rabbit granulocytes. Infect. Immun. 70, 569-576.

Zhao, C., Liu, L., and Lehrer, R.I. (1994). Identification of a new member of the protegrin family by cDNA cloning. FEBS Lett. 346, 285-288.

Zhao, C., Ganz, T., and Lehrer, R.I. (1995a). The structure of porcine protegrin genes. FEBS Lett. 368, 197-202.

Zhao, C., Ganz, T., and Lehrer, R.I. (1995b). Structures of genes for two cathelin-associated antimicrobial peptides: prophenin-2 and PR-39. FEBS Lett. 376, 130-134.

Zhao, C., Nguyen, T., Boo, L.M., Hong, T., Espiritu, C., Orlov, D., Wang, W., Waring, A., and Lehrer, R.I. (2001). RL-37, an alpha-helical antimicrobial peptide of the rhesus monkey. Antimicrob. Agents Chemother. 45, 2695-2702. 


\section{Further Reading}

Caister Academic Press is a leading academic publisher of advanced texts in microbiology, molecular biology and medical research. Full details of all our publications at caister.com

- MALDI-TOF Mass Spectrometry in Microbiology Edited by: M Kostrzewa, S Schubert (2016) www.caister.com/malditof

- Aspergillus and Penicillium in the Post-genomic Era Edited by: RP Vries, IB Gelber, MR Andersen (2016) www.caister.com/aspergillus2

- The Bacteriocins: Current Knowledge and Future Prospects Edited by: RL Dorit, SM Roy, MA Riley (2016)

www.caister.com/bacteriocins

- Omics in Plant Disease Resistance Edited by: V Bhadauria (2016) www.caister.com/opd

- Acidophiles: Life in Extremely Acidic Environments Edited by: R Quatrini, DB Johnson (2016) www.caister.com/acidophiles

- Climate Change and Microbial Ecology: Current Research and Future Trend

Edited by: J Marxsen (2016)

www.caister.com/climate

- Biofilms in Bioremediation: Current Research and Emerging Technologies

Edited by: G Lear (2016)

www.caister.com/biorem

- Microalgae: Current Research and Applications Edited by: MN Tsaloglou (2016) www.caister.com/microalgae

- Gas Plasma Sterilization in Microbiology: Theory, Applications, Pitfalls and New Perspectives Edited by: H Shintani, A Sakudo (2016) www.caister.com/gasplasma

- Virus Evolution: Current Research and Future Directions Edited by: SC Weaver, M Denison, M Roossinck, et al. (2016) www.caister.com/virusevol

- Arboviruses: Molecular Biology, Evolution and Control Edited by: N Vasilakis, DJ Gubler (2016) www.caister.com/arbo

- Shigella: Molecular and Cellular Biology Edited by: WD Picking, WL Picking (2016) www.caister.com/shigella

-Aquatic Biofilms: Ecology, Water Quality and Wastewater Treatment

Edited by: AM Romaní, H Guasch, MD Balaguer (2016)

www.caister.com/aquaticbiofilms

- Alphaviruses: Current Biology

Edited by: S Mahalingam, L Herrero, B Herring (2016)

www.caister.com/alpha

- Thermophilic Microorganisms

Edited by: F Li (2015)

www.caister.com/thermophile
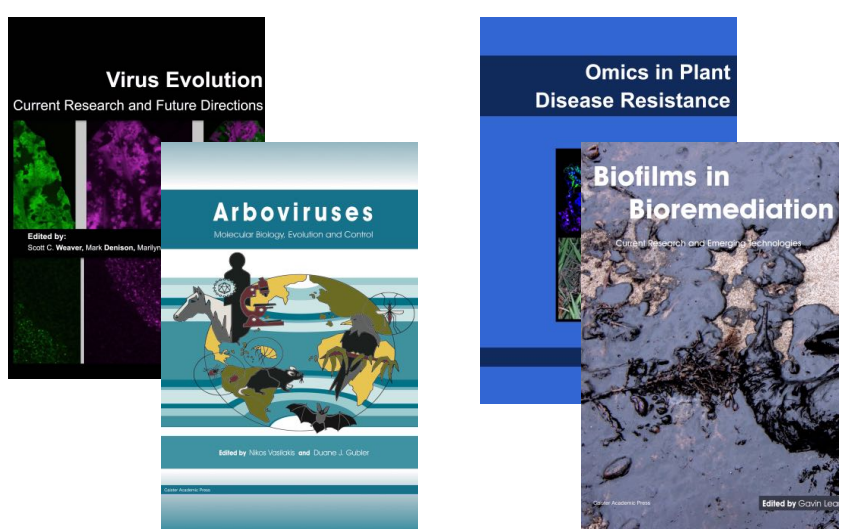
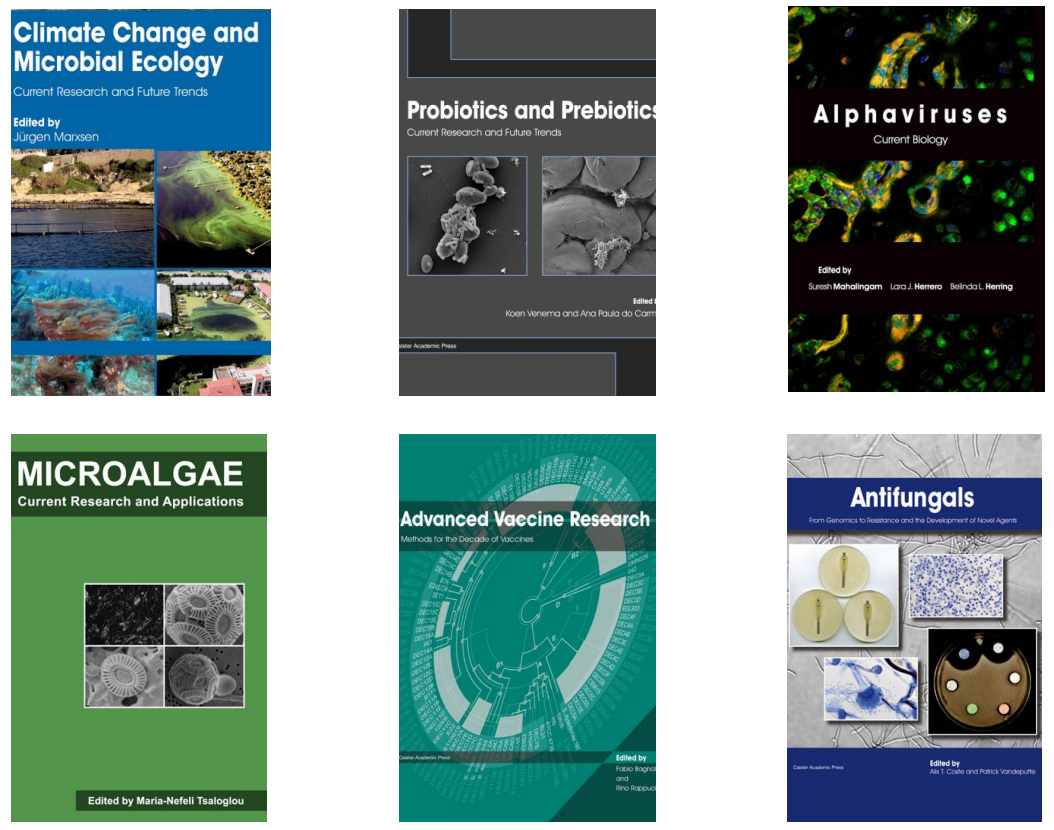

- Flow Cytometry in Microbiology: Technology and Applications Edited by: MG Wilkinson (2015) www.caister.com/flow

- Probiotics and Prebiotics: Current Research and Future Trends Edited by: K Venema, AP Carmo (2015) www.caister.com/probiotics

- Epigenetics: Current Research and Emerging Trends Edited by: BP Chadwick (2015) www.caister.com/epigenetics2015

- Corynebacterium glutamicum: From Systems Biology to Biotechnological Applications

Edited by: A Burkovski (2015)

www.caister.com/cory2

- Advanced Vaccine Research Methods for the Decade of Vaccines

Edited by: F Bagnoli, R Rappuoli (2015)

www.caister.com/vaccines

- Antifungals: From Genomics to Resistance and the Development of Novel Agents

Edited by: AT Coste, P Vandeputte (2015)

www.caister.com/antifungals

- Bacteria-Plant Interactions: Advanced Research and Future Trends Edited by: J Murillo, BA Vinatzer, RW Jackson, et al. (2015) www.caister.com/bacteria-plant

\section{- Aeromonas}

Edited by: J Graf (2015)

www.caister.com/aeromonas

- Antibiotics: Current Innovations and Future Trends

Edited by: S Sánchez, AL Demain (2015)

www.caister.com/antibiotics

- Leishmania: Current Biology and Contro Edited by: S Adak, R Datta (2015) www.caister.com/leish2

- Acanthamoeba: Biology and Pathogenesis (2nd edition) Author: NA Khan (2015)

www.caister.com/acanthamoeba2

- Microarrays: Current Technology, Innovations and Applications Edited by: Z He (2014)

www.caister.com/microarrays2

- Metagenomics of the Microbial Nitrogen Cycle: Theory, Methods and Applications

Edited by: D Marco (2014)

www.caister.com/n2 